\title{
Non-helical Helicobacter pylori show altered gland colonization and elicit less gastric pathology during chronic infection
}

Laura E. Martínez ${ }^{1,2}$, Valerie P. O’Brien², Christina K. Leverich ${ }^{2}$, Sue E. Knoblaugh ${ }^{3}$, Nina R. Salama ${ }^{1,2^{*}}$

${ }^{1}$ Graduate Program in Pathobiology, Department of Global Health, University of Washington, Seattle, WA, 98195, USA.

${ }^{2}$ Division of Human Biology, Fred Hutchinson Cancer Research Center, Seattle, WA, 98109, USA.

${ }^{3}$ Department of Veterinary Biosciences, The Ohio State University, Columbus, OH, 43210, USA.

${ }^{*}$ Correspondence to: nsalama@fredhutch.org

Keywords: Helicobacter pylori, helical cell shape, gastric colonization, pathology, chronic infection

Running title: Non-helical Helicobacter pylori elicit less pathology

Current address for Laura E. Martínez: University of California Los Angeles, Los Angeles, CA 90095

\section{Abstract}

Half of all humans harbor Helicobacter pylori in their stomachs. Helical cell shape is thought to facilitate $H$. pylori's ability to bore into the protective mucus layer in a corkscrew-like motion, thus enhancing colonization of the stomach. H. pylori cell shape mutants show impaired colonization of the mouse stomach, highlighting the importance of cell shape in infection. To gain a deeper understanding of how helical cell morphology promotes host colonization by H. pylori, we used 3D-confocal microscopy to visualize the clinical isolate PMSS1 and an isogenic straight rod mutant $(\Delta \operatorname{csd} 6)$ within thick longitudinal mouse stomach sections and performed volumetric image analysis to quantify the number of bacteria residing within corpus and antral glands in addition to measuring total colony forming units (CFU). We found that straight rods show attenuation during acute colonization of the stomach (one day or one week post-infection) as measured by total CFU. Our quantitative imaging revealed that wild-type bacteria extensively colonized antral glands at one week post-infection, while csd6 mutants showed variable colonization of the antrum at this timepoint. During chronic infection (one or three months postinfection), total CFU were highly variable, but similar for wild-type and straight rods. Both wildtype and straight rods persisted and expanded in corpus glands during chronic infection. However, the straight rods showed reduced inflammation and disease progression. Thus, helical cell shape contributes to tissue interactions that promote inflammation during chronic infection, in addition 


\section{Introduction}

Helicobacter pylori is a Gram-negative, helical shaped bacterium that has evolved to survive in the human stomach. $H$. pylori chronically colonizes the gastric mucosa of approximately $20 \%$ of the population in developed countries and greater than $70 \%$ of the population in the developing world (1). Most $H$. pylori infections are asymptomatic; however, chronic infection increases the risk of developing chronic active gastritis, peptic ulcer disease, duodenal ulcers, gastric adenocarcinoma, and gastric extranodal marginal zone lymphoma of mucosa-associated lymphoid tissue type (MALT lymphoma) (2). The stomach is an unfavorable environment for bacteria due to its acidity, active digestive enzymes, and low partial oxygen pressure. As a neutrophile, $H$. pylori can only survive minutes in the stomach lumen and overcomes the acidic environment using urease, an enzyme that hydrolyzes urea to produce $\mathrm{NH}_{3}$, locally elevating the $\mathrm{pH}$ to near neutral. Successful colonization of the stomach by H. pylori requires both urease (3-6) and flagellarmediated, chemosensory-directed motility to swim out of the lumen and through the mucus layer (7-10). Helical cell shape is thought to facilitate H. pylori's ability to bore into the mucus layer in a corkscrew-like motion, further enhancing its motility through the highly viscous gastric mucus layer that overlies the gastric epithelium. Upon penetrating this thick $(\sim 300 \mu \mathrm{m})$ mucus layer, $H$. pylori preferentially colonizes a narrow band ( $\sim 25 \mu \mathrm{m}$ thick) of mucus immediately overlying the gastric epithelial cell surface (11). While $H$. pylori actively adheres to gastric epithelial cells, it remains extracellular and is only rarely observed within cells (12-14). Upon attachment, $H$. pylori disrupts the tight junctions of epithelial cells to exploit them as a site for replication, where the bacteria can grow as cell-associated microcolonies (15). H. pylori also penetrates gastric pits and grows in microcolonies deep in the gastric glands (8).

The helical cell shape of $H$. pylori is generated and maintained by the peptidoglycan (PG) cell wall (16, 17). PG modifying enzymes (Csd1, Csd2, Csd3/HdpA, Csd4, and Csd6) are required to maintain helical cell shape in $H$. pylori (16-22). We and others have shown that H. pylori cell shape mutants ( $\Delta c s d 1$ curved rod and $\Delta c s d 3$ variably "c"-shaped rod mutants) are attenuated in stomach colonization $(16,19)$. Straight rod mutants $(\Delta c s d 4)$ also show reduced stomach

71 colonization loads and are outcompeted by wild-type bacteria during co-infection (17). The cell 72 shape mutants do not show a defect in their ability to infect human gastric adenocarcinoma (AGS) 73 cells in vitro or to release the pro-inflammatory cytokine interleukin-8 (IL-8) (17). We previously 
74 showed that variation in both cell body helical parameters (helical pitch and radius) and flagellum 75 number among different $H$. pylori clinical isolates (LSH100, PMSS1, and B128) leads to distinct 76 and broad swimming speed distributions that reflect both temporal variation in the swimming 77 speed of individual bacterial cells and morphologic variation within the population (23). 78 Furthermore, isogenic mutants with straight rod morphology $(\Delta c s d 6)$ showed reduced swimming 79 speeds and a higher fraction of immobilized bacteria in purified gastric mucin gels (23). Whether 80 altered motility behavior in mucus fully accounts for the altered stomach colonization potential of 81 cell shape mutants remains an open question.

83 Different $H$. pylori strains preferentially colonize the corpus or antrum of the human stomach. The 84 inner lining of the stomach consists of four layers, the serosa, muscularis, submucosa, and mucosa.

85 The mucosa is densely packed with branched tubular gastric glands. Corpus glands are mostly 86 comprised of chief cells, which secrete pepsin, and parietal cells, which secrete hydrochloric acid.

87 The antrum, which comprises about one-fourth of the stomach, is lined by glands mostly containing mucus secreting cells and endocrine cells. Chronic infection with $H$. pylori triggers inflammation in the corpus or antrum, further resulting in distinct disease outcomes. Antralpredominant gastritis is associated with increased acid production, a risk factor for duodenal ulcers $(24,25)$. Corpus-predominant gastritis leads to loss of parietal cells and eventual reduced acid secretion, increasing the risk for gastric cancer $(24,26,27)$. As in the human stomach, $H$. pylori can colonize both the corpus and antrum regions of the mouse gastric mucosa (28). The mouse stomach contains two grossly distinct stomach regions, a non-glandular (forestomach) region and

95 a glandular region (corpus and antrum). The forestomach, which does not become colonized by $H$. pylori, is lined with keratinized squamous epithelium and is separated from the glandular corpus

97 region by a raised mucosal fold referred to as the limiting ridge. Several mouse-adapted H. pylori 98 isolates induce gastritis and gland atrophy in C57BL/6 mice, but do not induce neoplasia (29, 30).

99 However, chronic infection with PMSS1, a strain shown to be more virulent than other clinical

100 isolates in mice, triggers inflammation, gland hyperplasia, gastric atrophy, and early signs of 101 metaplasia $(31,32)$.

102

103 Here, we used a mouse model of infection to investigate how helical cell shape helps H. pylori 104 establish infection and acquire a replicative niche within the stomach. In addition to enumerating 
colony forming units (CFU) of $H$. pylori in homogenized stomach tissue, we used 3D-confocal microscopy and volumetric image analysis to localize and quantify the number of bacteria present within corpus and antral glands. We discovered that $\Delta c s d 6$ straight rods are attenuated at one day and one week post-infection, both in CFU load and localization within gastric glands, yet can nonetheless establish chronic infection. At one week post-infection, straight rods show reduced localization within antral glands, while at one month post-infection, localization within both antral and corpus glands is similar to or greater than that of wild-type $H$. pylori. In spite of their ability to localize within the glands, $\Delta c s d 6$ straight rods elicited less inflammation and hyperplasia in the antrum and the transition zone between corpus and antrum at one and three months post-infection. Our study supports a role for helical cell shape in promoting efficient stomach colonization during acute infection and in driving gastric pathology during chronic infection.

\section{Results}

\section{Csd6-dependent helical cell shape of $\mathrm{H}$. pylori confers an advantage during initial colonization of the stomach}

To investigate how helical cell morphology contributes to $H$. pylori stomach colonization and persistence, we conducted single-strain infections and competitions with wild-type $H$. pylori PMSS1 and an isogenic straight rod mutant $(\Delta c s d 6$, Table S1). We harvested a third of the stomach to assess bacterial load by colony-forming units (CFU) per gram of stomach tissue, a third to fix in paraformaldehyde for immunohistochemistry for enumeration of bacteria within gastric glands, and a third for pathological evaluation (Fig. 1). As expected, we did not recover H. pylori from the mock-infected groups at any time point (data not shown). The $\Delta c s d 6$ straight rod mutant showed significantly attenuated gastric loads at one day with a two log difference in CFU/g of stomach tissue compared to wild-type ( $p<0.0001$, unpaired non-parametric two-tailed Mann Whitney $U$ test) (Fig. 2A). At one week, the mutant had a one log difference in recovery compared to wildtype $(p<0.0001)$, as had been previously reported for another straight rod mutant $(\Delta c s d 4)$ generated in a different $H$. pylori strain background (LSH100) (17). In a competition experiment, wild-type bacteria strongly outcompeted the $\Delta c s d 6$ mutant at one week post-infection $(p=0.0005$, paired t-test) (Fig. 2B). Complementation of the $\Delta c s d 6$ mutant by expressing the $\operatorname{cs} d 6$ gene at a distal intragenic locus $(22,33)$, restored helical cell shape and no significant differences in side 
135 curvature distributions were observed between wild-type and the $c s d 6$ complemented strain $(p=$ 136 0.6, Kolmogorov-Smirnov statistics) (Fig. S1). In mice, the csd6 complemented strain showed 137 comparable colonization loads to the wild-type strain at one day post-infection, but interestingly 138 was comparable to the $\Delta c s d 6$ mutant at one week post-infection (Fig. 2A). However, in 139 competitive infection, the $\Delta c s d 6$ mutant was outcompeted by the csd6 complemented strain in 6 140 of 10 mice at one week in two independent experiments (Fig. 2B). Taken together, these data 141 suggest that the csd6 complemented strain has some shape-independent colonization defect that 142 manifests after the first day of infection. Nonetheless, we tested both the deletion strain and the 143 complemented strain in subsequent experiments.

3D-volumetric image analysis of $\mathbf{H}$. pylori indicates an antral gland preference for both wildtype and straight rod mutant bacteria during acute infection

148 Others have shown that during experimental infection in C57BL/6 mice, $\mathrm{H}$. pylori bacteria reside 149 in the mucus layer that overlies the stomach epithelium and a subpopulation of bacteria penetrate 150 deep in the gastric glands, where they can adhere to gastric epithelial cells comprising the mid151 glandular proliferative zone $(8,32)$. We questioned whether the $\Delta$ csd6 mutant could occupy the 152 same niches. In thin $(4-5 \mu \mathrm{m})$ sections, H. pylori is difficult to quantify, because the gastric gland 153 lumen is rarely captured. Thus, we followed a recently established method for 3D-confocal 154 microscopy to visualize and quantify the number of $H$. pylori bacteria colonizing corpus and antral 155 glands in thick $(100-200 \mu \mathrm{m})$ sections using volumetric image analysis of individual bacterial cells 156 and bacteria within microcolonies $(8,32)$. Similar to prior studies, the mean volume for individual 157 cells analyzed was $9.5 \mu \mathrm{m}^{3}(\mathrm{n}=203$ cells analyzed) and clusters of two bacteria showed a 158 proportional increase in volume (Fig. S2).

160 At one day post-infection, both wild-type and the $\Delta c s d 6$ mutant were detected in corpus and antral 161 glands at very low densities (data not shown). At one week, 3D-visualization of the antrum showed 162 wild-type bacteria associated with gastric epithelial cells near the luminal surface, as well as deeper 163 in the glands, where they form dense microcolonies (Fig. 3A). To explore bacterial localization 164 differences among strains, we quantified the number of bacteria in each field of view along the 
165 length of the stomach for one mouse from each genotype with similar colonization loads (Fig. 3B$166 \mathrm{D}$; wild-type $7.6 \times 10^{5} \mathrm{CFU} / \mathrm{g}, \Delta \operatorname{csd} d 64.0 \times 10^{5} \mathrm{CFU} / \mathrm{g}, \operatorname{csd} 6 \mathrm{comp} .5 .4 \times 10^{5} \mathrm{CFU} / \mathrm{g}$ ). Wild-type

167 bacteria were easily detected in antral glands and the transition zone between the corpus and 168 antrum (C/A) junction (Fig. 3B). Fewer bacteria were observed in corpus glands ( $<40$ bacteria per 169 field of view). The $\Delta c s d 6$ mutant bacteria were detectible but at lower numbers in both corpus and 170 antral glands (fewer bacteria per gland as well as fewer glands colonized) (Fig. 3C and S3A). Like 171 wild-type, csd6 complemented bacteria were observed predominantly in the antrum (Fig. 3D and $172 \mathrm{~S} 3 \mathrm{~B}$ ) and the $\mathrm{C} / \mathrm{A}$ junction. We extended this analysis to additional animals from each genotype 173 (Fig. 3E). In all animals infected with wild-type and csd6 complemented strains, as well as two 174 out of three animals infected with $\Delta c s d 6$, the bacteria preferentially localized to the antrum instead 175 of the corpus. However, the levels of bacteria detected in the glands did not correlate well with 176 CFU loads. While there was a trend toward lower levels of gland localization for $\Delta c s d 6$ compared 177 to wild-type and csd6 complemented bacteria, the $\Delta c s d 6$ mutant was able to penetrate and multiply 178 within both corpus and antral glands in at least a subset of animals, despite exhibiting a significantly lower CFU load at this time point.

\section{Both helical H. pylori and straight rods show expansion into the corpus after one month}

182 At one month post-infection, we observed a wide distribution of stomach loads from all strains 183 tested, but in each case the geometric mean was around $10^{5} \mathrm{CFU} / \mathrm{g}$ (Fig. 4A). A subset of mice 184 showed stomach loads of $10^{6} \mathrm{CFU} / \mathrm{g}$ or more, while other mice showed low loads near or below 185 the limit of detection $\left(10^{3} \mathrm{CFU} / \mathrm{g}\right)$. At three months, stomach loads from each infected group were 186 more tightly clustered, though the geometric mean was still around $10^{5} \mathrm{CFU} / \mathrm{g}$ (Fig. 4A). Thus, 187 Csd6-mediated helical cell shape is necessary for robust stomach colonization during the acute 188 stages of gastric infection in mice, but not for maintenance of chronic infection.

190 Given the variable stomach CFUs at one month (Fig. 4A), we determined the localization of 191 bacteria in gastric tissue samples with either "low" $\left(\sim 10^{4} \mathrm{CFU} / \mathrm{g}\right.$ of stomach $)$ or "high" $\left(\sim 10^{6}\right.$ $192 \mathrm{CFU} / \mathrm{g}$ of stomach) bacterial loads of the three strains (Fig. 4B). We observed two key differences 193 from the one week analysis (compare to Fig. 3E): first, the total number of bacteria quantified at 194 one month was generally lower than at one week; and second, at one month there were more 195 bacteria in the corpus than the antrum - the reverse of what was observed at one week. For mice 
with a "low" CFU load (Fig. 4C, left panels), the numbers of bacteria detected in corpus glands were similar among bacterial genotypes (fewer than 75 total bacteria). However, both the $\Delta c s d 6$ and the csd6 complemented strains had more bacteria in the antrum (22 and 23 total bacteria, respectively) than the wild-type strain did (one bacterium). For mice with a "high" CFU load (Fig. $4 \mathrm{C}$, right panels), the $\Delta c s d 6$ mutant was different from the other two strains, with more bacteria detected in the corpus (849) than the antrum (96). The wild-type and csd6 complemented strains

202 had more similar numbers of bacteria in the corpus (52 and 122, respectively) and antrum (37 and 203 94, respectively). While we did detect more total bacteria in the "high" CFU mice than their "low" 204 CFU counterparts, CFU load did not correlate well with the number of bacteria detected in the 205 glands.

\section{Chronic infection with the straight rod mutant results in reduced inflammation}

207 Next, we assessed pathologic responses in mice infected with the different genotypes. The most 208 severe lesions in each animal were scored according to previously developed pathology scoring 209 criteria for inflammation, epithelial defects, oxyntic atrophy, hyperplasia, and metaplasia in the 210 corpus and inflammation and hyperplasia in the antrum (Table S2 and (34)). Individual scores (0-

211 4) for each criterion were summed to generate a histological activity index (HAI) score. At one 212 and three months post-infection, animals showed evidence of both inflammation and hyperplasia 213 throughout the stomach. As shown in Fig. 5, which show representative images of animals with 214 the highest HAI score for each genotype, pathologic changes were most pronounced at the 215 corpus/antrum junction (C/A). Oxyntic atrophy (loss of parietal cells) and metaplasia were also 216 observed within the distal corpus near the C/A junction (e.g. Fig. 5B).

218 At one month post-infection, wild-type and csd6 complemented bacteria induced inflammation 219 characterized by lymphocytic and neutrophilic infiltrates and low level oxyntic atrophy at the 220 antrum and $\mathrm{C} / \mathrm{A}$ junction. In contrast, mice infected with the $\Delta c s d 6$ mutant had little to no gastric 221 inflammation and reduced hyperplasia (Fig. 6A and S4A-B), even though about half the mice had 222 fairly high bacterial loads and bacteria were detected within gastric glands at this time point (Fig. 223 4A). The differences in pathology among bacterial genotypes became more pronounced at three 224 months (Fig. 6A and S4C-D), by which time the $\Delta c s d 6$ mutant infected animals showed 225 significantly reduced HAI scores and individual scores for inflammation, oxyntic atrophy, and 
226 hyperplasia in the C/A junction (Fig. S4C-D). Animals infected with wild-type bacteria showed 227 evidence of an inverse relationship between stomach CFU load and HAI (Spearman correlation 228 coefficient $r=-0.22$, Fig. 6B), which is consistent with prior studies showing lower loads in 229 animals with more severe gastritis (35). In contrast, animals infected with the $\Delta c s d 6$ mutant 230 showed the opposite trend (Spearman correlation coefficient $r=0.518$, Fig. 6B). Thus, although 231 bacterial loads are not statistically significantly different at three months post-infection (Fig. 4A), 232 the $\Delta c s d 6$ mutant elicits significantly less inflammation and hyperplasia compared to wild-type or 233 the $\operatorname{csd} 6$ complemented strain at this time point.

\section{Discussion}

237 It has long been proposed that helical cell shape facilitates H. pylori's ability to penetrate the thick 238 gastric mucus layer by enhancing cell body propulsion, thus promoting colonization of the stomach 239 (36). Our study confirms and extends prior results that helical cell shape, while not required for 240 stomach colonization, confers a significant advantage to $H$. pylori during acute infection (one day 241 and one week) $(16,17)$. During chronic infection, the colonization levels of the wild-type strain 242 and the $\Delta c s d 6$ mutant were comparable, suggesting that the mutant can nonetheless chronically 243 colonize glands of the stomach. Thus, straight rods may occupy a specific niche within the stomach 244 allowing them to persist long-term. By performing 3D image analysis of $H$. pylori in thick stomach 245 sections we found that wild-type and csd6 complemented H. pylori had reduced localization within 246 corpus and antral glands at one month post-infection relative to the number of bacteria observed 247 in the glands at one week, which may be attributed to adaptive immune responses clearing the 248 infection (35). While $\Delta c s d 6$ infected tissues appeared to have somewhat lower levels of bacteria 249 within the glands at one week, the contraction of the gland population at one month appeared less 250 dramatic, particularly in the corpus. Our fixation conditions do not preserve the mucus layer 251 overlying the epithelium, which may host a significant fraction of bacteria in both mutant and wild252 type infections. Finally, we found that the $\Delta c s d 6$ mutant elicited less inflammation than wild-type 253 or complemented bacteria at one and three months post-infection, despite having comparable 254 bacterial CFU loads and similar or greater localization within the gastric glands. Thus, our study 255 is the first to suggest a bacterial load-independent link between H. pylori's helical cell shape and 256 chronic gastritis. 
258 During chronic infection with H. pylori, the degree of inflammation found at the corpus/antrum 259 junction is often greater than observed in the adjacent mucosa of either the corpus or antrum, and 260 may promote glandular atrophy, loss of parietal cells in the corpus, and eventually mucous cell gland hyperplasia (37). In the present study, we found highly variable colonization loads in mice infected with either wild-type, the $\Delta c s d 6$ mutant, or the $\operatorname{csd} 6$ complemented strain for one month, which may be related to differential host responses among mice. Chronic infection with wild-type PMSS1 or the csd6 complemented strain induced pathology in the antrum and the C/A junction. However, straight rods elicited less inflammation and gland hyperplasia. Chronic infection with H. pylori is controlled by innate and adaptive immune responses, regulated by $\mathrm{CD}^{+} \mathrm{T}$-helper 1 (Th1), Th17-polarized T-effector cell subsets, B-cells, and their secreted cytokines $(35,38)$.

Evaluating the adaptive immune response to infection with the $\Delta c s d 6$ mutant will determine if its differential localization in corpus glands at one month influenced its ability to induce inflammation or cause gastric disease. In addition, some H. pylori strains, including PMSS1 used in this study, express VacA, a virulence factor that has been shown to suppress T-cell responses to mediate longevity of infection (39-41). It will also be important to determine whether $H$. pylori cell shape mutants have unexpected effects on the expression of other factors that could mediate or suppress inflammation, such as VacA, to maintain a favorable niche in the stomach.

Our work demonstrates that the helical cell shape of $H$. pylori is important for acute colonization of the stomach and enhances pathology during chronic infection. Helical cell shape is also important for a bacterial pathogen that colonizes the human intestinal tract, Campylobacter jejuni. Isogenic straight rod mutants of C. jejuni pgp1 and pgp2 (homologs of H. pylori csd4 and csd6, respectively) show attenuated motility in soft agar $(42,43)$ similar to H. pylori. However, C. jejuni pgpl and pgp2 mutants completely fail to colonize intestinal crypts or to induce inflammatory

282 responses in the mouse model tested (44).

284 In summary, our study provides insight into how helical cell shape impacts $H$. pylori's niche 285 acquisition and inflammation in the stomach. Loss of helical cell shape alters $H$. pylori's ability to 286 utilize some of the available niches within the stomach and its ability to promote inflammation and 287 tissue hyperplasia when present in the glands. As morphological diversity exists between different 
clinical isolates of $H$. pylori in cell body and helical cell parameters (23), H. pylori clinical isolates with decreased helical pitch and twist may differ in their ability to colonize certain gastric niches and in the trajectories of pathogenesis. Thus, diversity in cell shape parameters may contribute to the diversity of pathogenic outcomes observed in infected individuals.

Materials and Methods

H. pylori strains and growth conditions. Strains used in this study are described in Table S1. Briefly, wild-type H. pylori strain PMSS1, also called 10700 (31, 45), and derivatives were cultured on horse blood plates or in liquid media containing 90\% (v/v) Brucella broth (BD Biosciences) and 10\% fetal bovine serum (GIBCO) (BB10) in the absence of antimicrobials, as previously described (16). Cells were maintained at $37^{\circ} \mathrm{C}$ under microaerobic conditions in a trigas incubator equilibrated to $10 \% \mathrm{CO}_{2}$ and $10 \% \mathrm{O}_{2}$. Plates were incubated 24-72 hours and liquid cultures were incubated for 12-16 hours under constant agitation at $200 \mathrm{rpm}$. For resistance marker selection, horse blood plates were supplemented with chloramphenicol $(15 \mu \mathrm{g} / \mathrm{mL})$ or kanamycin $(25 \mu \mathrm{g} / \mathrm{mL})$.

Strain construction. Isogenic mutant of csd6 (HPG27_477) in the PMSS1 strain background was generated by transfer of the mutation constructed in the G27/LSH100 strain background $(16,22)$ using natural transformation (46). Transformants were confirmed by PCR using primers homologous to upstream and downstream flanking regions of the gene using the primers listed in Table S2. The mutation was then backcrossed into PMSS1 once by isolating genomic DNA from the resulting strain for natural transformation of PMSS1. The resulting backcrossed clones were evaluated by PCR to confirm replacement of the wild-type allele with the null allele. Clones were

312 checked for urease activity and motility, and single clones were used for quantitative morphology

313 analysis and for oral gavage of mice.

315 The $\operatorname{csd} 6$ complemented strain was constructed by natural transformation of PMSS1 $\Delta c s d 6$ with 316 genomic DNA from a csd6 complemented strain generated in the $H$. pylori G27 strain background, 317 TSH31 (Acsd6::cat McGee:csd6:aphA3), where a wild-type copy of csd6 (HPG27_477) was 318 introduced at a neutral intergenic chromosomal locus (33). Genomic DNA from TSH31 was used 
319 for natural transformation of the PMSS1 $\Delta c s d 6$ strain. Transformants were selected on horse blood 320 plates supplemented with kanamycin $(25 \mu \mathrm{g} / \mathrm{mL})$. The recipient strain (EPH1) was PCR confirmed 321 using primers homologous to upstream and downstream flanking regions using the primers listed 322 in Table S1. The csd6 complemented strain was then backcrossed once by isolating genomic DNA 323 from EPH1 for natural transformation of PMSS1 $\Delta c s d 6$. The resulting backcrossed clones were 324 evaluated by PCR to confirm integration of $c s d 6$ and were renamed LMH12 clones 1-3. The clones 325 were then checked for urease activity and motility, and were used for quantitative morphology 326 analysis. Figure S1 shows morphology analysis of LMH12 clone 3 (csd6 complemented strain), 327 which was the strain used for single-strain infections in mice and for bacterial localization studies.

Morphology analysis. Wild-type $H$. pylori PMSS1, $\Delta c s d 6$, and csd6 complemented bacteria were grown in liquid culture to an optical density at $600 \mathrm{~nm}$ (O.D. (600)) of $0.4-0.6$. Bacteria was fixed in 4\% Paraformaldehyde with 25\% Glycerol in $1 \mathrm{X}$ PBS and added to 0.1\% Poly-L-lysine (Sigma Aldrich) coated coverslips, which were then placed on a pre-cleaned microscope slide and sealed with VaLP (1:1:1 Vaseline: Lanolin: Paraffin). Single focal plane images were collected using a 100X ELWD Plan APO (NA 1.40 oil) objective mounted on a Nikon TE 200 microscope, equipped with a Nikon CoolSNAP HQ CCD camera controlled by MetaMorph software (MDS Analytical Technologies). Quantitative morphology analysis of manually thresholded phase-contrast images was performed as described in Sycuro et al. 2010 using the CellTool software program $(16,47)$.

Parameter optimization for $\boldsymbol{H}$. pylori 3D-image analysis. Wild-type $H$. pylori PMSS1 bacteria was grown in liquid culture to an optical density at $600 \mathrm{~nm}$ (O.D. (600)) of $0.4-0.6$. A $1 \mathrm{~mL}$ of

341 bacterial culture was harvested in a $1.5 \mathrm{~mL}$ microcentrifuge tube and centrifuged at 5,000 rpm for

$3425 \mathrm{~min}$. The cell pellet was resuspended in 100-200 $\mu \mathrm{L}$ of $4 \%$ Paraformaldehyde (PFA) in $100 \mathrm{mM}$

343 phosphate buffer ( $\mathrm{pH} 7.4$ ) and fixed for at least $30 \mathrm{~min}$ at room temperature. Bacteria were then 344 embedded in 4\% agarose (ultra-pure low-melting point agarose, Invitrogen) prepared in 1X 345 phosphate-buffered saline ( $\mathrm{pH} 7.4$ ) (Gibco). The agarose solution was first cooled down to $~ 55$ $34665^{\circ} \mathrm{C}$ and then aliquoted into $1.5 \mathrm{~mL}$ microcentrifuge tubes. Aliquots of fixed bacteria were 347 immediately added and gently resuspended into the solution before it solidified. The solidified 348 slabs were gently removed by insertion of a metal spatula on the side of the tube. The slabs were 349 then sectioned using a vibratome (Leica VT $1200 \mathrm{~S}$ fully automated vibrating blade microtome, 
350 Leica Biosystems, Germany) to generate 100 - $200 \mu \mathrm{m}$ thick sections. Sections were permeabilized 351 in blocking buffer (3\% bovine serum albumin (Sigma Aldrich); 1\% Saponin (Sigma Aldrich); and $3521 \%$ Triton X-100 (Sigma Aldrich) in 1X PBS) and immunostained with primary anti-H. pylori 353 rabbit polyclonal antibody (1:1,000 dilution) (gifted by Dr. Manuel Amieva at Stanford 354 University) overnight at $4^{\circ} \mathrm{C}$. A goat anti-rabbit Alexa Fluor-488 conjugate antibody $(1: 2,000)$ 355 (Molecular Probes) was used to visualize H. pylori. Samples were incubated in the secondary 356 antibody for $2 \mathrm{hrs}$ at room temperature. Sections were then washed $5 \mathrm{X}$ with blocking buffer and 357 then mounted onto standard glass microscope slides with secure imaging spacers ( 9 mm diameter 358 x $0.12 \mathrm{~mm}$ depth, Electron Microscopy Sciences). Pro-Long Diamond Antifade medium was 359 added (Molecular Probes) before mounting on coverslips.

361 Ethics statement. All procedures involving animals were done under practices and procedures of 362 Animal Biosafety Level 2 and carried out with strict accordance with the recommendations in the 363 Guide for the Care and Use of Laboratory Animals of the National Institutes of Health. The facility 364 is fully accredited by the Association for Assessment and Accreditation of Laboratory Animal 365 Care and complies with the United States Department of Agriculture, Public Health Service, 366 Washington State, and local area animal welfare regulations. All activities were approved by the 367 FHCRC Institutional Animal Care and Use Committee (IACUC; protocol number 1531). Animals were euthanized by $\mathrm{CO}_{2}$ asphyxiation followed by cervical dislocation.

Mouse infections. 4-6 week old female C57BL/6J mice were purchased from the Jackson Laboratory (Bar Harbor, Maine, U.S.) and were certified free of endogenous Helicobacter infection by the vendor. All animals were maintained in autoclaved microisolator cages (1-5 mice per cage) and provided with standard chow and water ad libitum. Mice were infected with a single

374 dose of $5 \times 10^{7} \mathrm{H}$. pylori cells/strain $(0.1 \mathrm{~mL})$ via oral gavage. Mock-infected controls were gavaged with $0.1 \mathrm{~mL}$ of liquid culture media containing $90 \%(\mathrm{v} / \mathrm{v})$ Brucella broth and 10\% fetal bovine serum (BB10); no H. pylori were recovered from mock-infected mice. Mice were euthanized by inhalation of $\mathrm{CO}_{2}$ and stomachs were harvested at one day, one week, and one or three months post-infection. Most of the non-glandular region (forestomach) was discarded since this region of the stomach is lined with squamous rather than glandular epithelium. H. pylori has not been shown to colonize this region of the stomach. However, H. pylori may colonize the 
interface between the squamous forestomach and glandular stomach where the corpus begins (the squamocolumnar junction). Regions of interest for $H$. pylori colonization include the corpus, antrum, and the pyloric junction with the duodenum. Therefore, part of the forestomach was maintained and the glandular stomach (corpus and antrum) was opened along the lesser curvature from the esophagus through the proximal duodenum. For one day and one week harvests, half the stomach was used for plating for CFU enumeration and the other half was fixed in $4 \%$ paraformaldehyde (PFA) in $100 \mathrm{mM}$ phosphate buffer (pH 7.4) for 1-2 hours. For chronic infection time points (one and three months), the stomach was divided into thirds. A third of the stomach was collected to measure CFU/gram of stomach load, a third was fixed in 4\% PFA for immunofluorescence, and a third was fixed in 10\% neutral buffered formalin (NBF) solution (Thermo Fisher Scientific) for histology. In each case, food was carefully removed and the stomach was laid flat on an index card and placed in a cassette with a sponge at top, closed, and fixed in its respective solution. For CFU counts, one-half or one-third stomachs were manually homogenized using a pestle in $0.5 \mathrm{~mL}$ of BB10. Serial 10-fold dilutions of stomach homogenate were plated on solid horse blood agar plates containing 4\% Columbia agar base (Oxoid, Hampshire, UK), 5\% defibrinated horse blood (HemoStat Labs, Dixon, CA) $0.2 \% \beta$-cyclodextrin (Sigma, St. Louis, MO), $10 \mu \mathrm{g} / \mathrm{mL}$ vancomycin (Sigma), $5 \mu \mathrm{g} / \mathrm{mL}$ cefsulodin (Sigma), $2.5 \mathrm{U} / \mathrm{mL}$ bacitracin $(200 \mu \mathrm{g} / \mathrm{mL})$ to eliminate normal mouse microbiota growth. Plates were incubated at $37^{\circ} \mathrm{C}$ using a tri-gas incubator $\left(10 \% \mathrm{CO}_{2}, 10 \% \mathrm{O}_{2}\right.$; Thermo Fisher Scientific) for 4-5 days.

Competition experiments. Mice were infected with a $1: 1$ ratio of $10^{7} \mathrm{CFU}$ or wild-type $H$. pylori and the isogenic straight rod mutant $(\Delta c s d \sigma)$ or the $c s d 6$ complemented strain. After one week, stomachs were removed, divided in half, and plated to determine bacterial loads as CFU/gram of stomach. Wild-type bacterial output was plated on horse blood plates containing the antibiotics described above. The $\Delta c s d 6$ mutant was selected on horse blood plates with chloramphenicol (15 $\mu \mathrm{g} / \mathrm{mL})$, and the $\operatorname{cs} d 6$ complemented strain was selected on horse blood plates with kanamycin (25

Immunofluorescence of thick longitudinal mouse stomach sections. Tissues from mouse $\mu \mathrm{g} / \mathrm{mL})$.

stomachs were processed for confocal immunofluorescence microscopy as described in $(8,32)$, 
412 with minor modifications. Gastric tissue was fixed in 4\% PFA for 1-2 hours at room temperature.

413 Tissue was embedded in 4\% agarose in 1X phosphate-buffered saline (PBS) (pH 7.4) (Gibco) and

414 sectioned using a vibratome to generate $100-200 \mu \mathrm{m}$ thick longitudinal sections that include the

415 limiting ridge at the forestomach/glandular junction to the pyloric junction with the duodenum.

416 Tissue sections were then permeabilized in blocking buffer (3\% bovine serum albumin (Sigma

417 Aldrich); 1\% Saponin (Sigma Aldrich); 1\% Triton X-100 (Sigma Aldrich)) in 1X PBS (pH 7.4)

418 (Gibco). Anti-H. pylori rabbit polyclonal antibody (1:1,000 dilution) was used to immunostain $H$.

419 pylori in the tissue overnight at $4^{\circ} \mathrm{C}$. The sections were then washed $5 \mathrm{X}$ with blocking buffer and 420 incubated with a goat anti-rabbit Alexa Fluor-647 conjugate antibody $(1: 2,000)$ to visualize

421 bacteria in tissue (Molecular Probes), and 4', 6-Diamidino-2-phenylindole (DAPI) $(0.1 \mu \mathrm{g} / \mathrm{mL})$ to

422 stain nuclei for $2 \mathrm{hrs}$ at room temperature. The sections were then washed $5 \mathrm{X}$ with blocking buffer 423 and mounted onto standard glass microscope slides with secure imaging spacers (20 mm diameter 424 x $0.12 \mathrm{~mm}$ thick, Electron Microscopy Sciences) or hand-made imaging spacers using parafilm 425 (0.12 mm thick). Pro-Long Diamond Antifade medium (Molecular Probes) was added before 426 mounting on coverslips.

428 Confocal microscopy. Tissue samples were imaged with a Zeiss LSM 780 NLO confocal and 429 multi-photon microscope with a $40 \mathrm{X}$ oil immersion objective lens (EC Plan-Neofluar $40 \mathrm{X} / 1.30$ 430 oil) and Z-stacks (355 $\mu \mathrm{m}(\mathrm{w}) \times 355 \mu \mathrm{m}(\mathrm{h}))$ were generated using the ZEN acquisition software 431 program. Images were acquired at a frame size of 1,024 x 1,024 with 8-bit depth and at a frame 432 rate speed of 8 frames per second. Z-stacks were generated with a slice interval of $0.5 \mu \mathrm{m}$ and 433 penetrated 40-50 $\mu \mathrm{m}$ into the section. For each tissue section, multiple Z-stacks (ranging from 25434 30) were acquired to capture the full length of longitudinal sections that include the limiting ridge 435 of the forestomach to the glandular junction to the pyloric junction with the duodenum. For all Z436 stacks, a collection of non-overlapping images was acquired by manual translation of the 437 microscope stage.

439 Volumetric image analysis and quantitation of $H$. pylori in the stomach. Quantitation of $H$. pylori 440 within individual gastric glands was performed using the Volocity 3D-image analysis software 441 program, as described in $(8,32)$, with minor modifications. 3D-reconstructed images were 442 imported onto Volocity and the total volume $\left(\mu \mathrm{m}^{3}\right)$ for individual bacterial cells was determined. 
443 The mean volume for a bacterium $\left(9.5 \mu \mathrm{m}^{3}\right)$ was used to calculate the total number of bacteria near

444 or at the surface epithelium and within gastric glands. The same measurement protocol was applied

445 across all tissue samples analyzed for wild-type $H$. pylori, the $\Delta c s d 6$ mutant, and for csd6 446 complemented bacteria. Analysis of 3 sections ( $>500 \mu \mathrm{m}$ apart) provided consistent results in 447 bacterial number counts. Our bacterial localization studies included analysis of 1-3 sections per 448 infected mouse. Three sections were analyzed per mouse after one week post-infection and 2-3 449 sections were examined per mouse at one month post-infection.

Histologic evaluation of $\mathbf{H}$. pylori infected stomachs. Longitudinal gastric strips from the lesser curvature that include the squamocolumnar junction through the proximal duodenum were fixed 453 in 10\% NBF. Samples were paraffin embedded, sectioned (5 $\mu \mathrm{m}$ thick), and stained with 454 Hematoxylin and Eosin (H\&E) by the Experimental Histopathology Core at the Fred Hutchinson 455 Cancer Research Center. Slides were interpreted and scored using the scoring criteria adapted from 456 (34), shown in Table S2, by a veterinary pathologist (S.E.K.) who was blinded to the experimental 457 details. The individual lesion scores of every mouse in each group were evaluated and compared 458 for inflammation, epithelial defects, oxyntic atrophy, hyperplasia, and metaplasia in the corpus 459 and inflammation and hyperplasia in the antrum. Individual scores (0-4) for each criterion were 460 summed to generate a histological activity index (HAI) score. 9-11 samples per group (mock461 infected, wild-type, $\Delta c s d 6$, and $\operatorname{csd} 6$ complemented strain) were evaluated at one and three months 462 post-infection.

464 Statistical analyses. We used the Kolmogorov-Smirnov (K-S) statistics tool in CellTool to assay 465 the differences in cell shape morphology, including cell length and side curvature distributions, as 466 described in $(16,17)$. For CFU data and histopathology scores, comparisons of three groups were 467 performed using a Kruskal-Wallis one-way analysis of variance (ANOVA) followed by Dunn's 468 multiple test corrections, and pairwise comparisons (competition experiments) were performed 469 with the Mann-Whitney U test using GraphPad Prism 7 (GraphPad Software, La Jolla, CA USA). $470 P<0.05$ was considered statistically significant. For the histological activity index (HAI), because 471 mucous metaplasia and hyalinosis may develop spontaneously in mice, these sub-scores were 472 excluded from the calculation of the total HAI. 
474 Acknowledgments. We thank Dr. Manuel Amieva for the wild-type H. pylori PMSS1 strain and 475 antibodies, Dr. Julie Huang for advice in preparing gastric tissue for 3-D confocal microscopy, and 476 Simran Handa (supported by a generous donation from the AT\&T Foundation to the FHCRC 477 Summer High School Internship Program) and Ericka Pegues for assistance in generating the csd6 478 complemented strain. This work was supported by the US National Institute of Health Grant R01 479 AI136946 to N.R.S., NIH Ruth L. Kirschstein National Research Service Award (NRSA) F31 480 AI098424 from the NIAID to L.E.M. This research was supported by the Comparative Medicine, 481 Electron Microscopy, Experimental Histopathology and Scientific Imaging Shared Resource of 482 the Fred Hutch/University of Washington Cancer Consortium (P30 CA015704). The content of 483 this article is solely the responsibility of the authors and does not necessarily represent the official 484 views of the National Cancer Institute and the National Institute of Allergy and Infectious 485 Diseases.

487 Author contributions. L.E.M and N.R.S. designed the study. L.E.M V.P.O and C.K.L. performed 488 experiments. L.E.M., V.P.O., C.K.L., and N.R.S. performed data analysis and interpretation. 489 S.E.K. evaluated samples for pathology. L.E.M, V.P.O, S.E.K., and N.R.S. wrote the manuscript.

491 Additional information. Supplementary information is available for this paper. Correspondence 492 and requests for materials should be addressed to N.R.S.

494 Competing financial interests. The authors declare no competing financial interests. 
Table 1. Bacterial strains used in this study.

500

\begin{tabular}{|c|c|c|c|}
\hline $\begin{array}{l}\text { Strain } \\
\text { Name }\end{array}$ & Genotype or Description & $\begin{array}{l}\text { Shape } \\
\text { phenotype }\end{array}$ & Reference or Source \\
\hline PMSS1 & Wild-type $H$. pylori & helical & $(31,45)$ \\
\hline LMH6 & $\Delta c s d 6: \because c a t$ in PMSS1 & straight & This study \\
\hline TSH17 & $\Delta c s d 6: \because c a t$ in LSH100 & straight & $(22)$ \\
\hline TSH31 & $\begin{array}{l}\Delta \mathrm{csd} \text { 6::cat McGee:csd6:aphA3 } \\
\text { in LSH100 }\end{array}$ & $\begin{array}{l}\text { helical and } \\
\text { straight } \\
\text { morphologies }\end{array}$ & $(22)$ \\
\hline EPH1 & $\begin{array}{l}\text { csd6 complemented strain: } \\
\Delta c s d 6:: \text { cat McGee:csd6:aphA3 } \\
\text { in PMSS1 }\end{array}$ & helical & This study \\
\hline LMH12 & $\begin{array}{l}\text { csd6 complemented strain: } \\
\text { EPH1 backcrossed in PMSS1 }\end{array}$ & helical & This study \\
\hline
\end{tabular}


Table S1. Primers used in this study.

\begin{tabular}{llll}
\hline $\begin{array}{l}\text { Gene } \\
\text { name }\end{array}$ & $\begin{array}{l}\text { H.pylorigene } \\
\text { annotation }\end{array}$ & Primer & Sequence \\
\hline
\end{tabular}

Targeted disruption primers

\begin{tabular}{llll}
\hline csd6 & $\begin{array}{l}\text { HPG27_477 } \\
(\text { HP0518) }\end{array}$ & HPG27_476 & Forward \\
& $\begin{array}{l}\text { HPG27_478 } \\
\text { Reverse }\end{array}$ & GCTGGTAGGAGATTGGTAATC \\
& & \\
\hline
\end{tabular}

Complementation primers

\begin{tabular}{llll}
\hline csd6 at & $\Delta c s d 6:$ :cat & McGee locus & GAGCGAGAATTCAAAGACAACCCCA \\
McGee & McGee: $c s d 6$ & Forward & \\
locus $^{\mathrm{d}}$ & aphA3 in & McGee locus & GGCGATGGGGCTGGGGCGTGCGTGATAGGC \\
& PMSS1 & Reverse & \\
& &
\end{tabular}

${ }^{\mathrm{a}}$ Gene annotation in the human clinical isolate G27 (48).

${ }^{\mathrm{b}}$ Gene annotation in the human clinical isolate 26695 (49).

${ }^{\mathrm{c}}$ Gene specific sequences are in uppercase and sequences added for cloning are in lower case. strain G27) (48). 
544 Table S2. Histopathologic scoring for inflammation and hyperplasia in mice chronically infected 545 with $H$. pylori for one and three months.

\begin{tabular}{|c|l|l|l|l|l|}
\hline Score & Inflammation & Hyperplasia & $\begin{array}{l}\text { Epithelial } \\
\text { defects }\end{array}$ & $\begin{array}{l}\text { Oxyntic } \\
\text { atrophy }\end{array}$ & Metaplasia \\
\hline $\mathbf{0}$ & $\begin{array}{l}\text { No } \\
\text { inflammation }\end{array}$ & No hyperplasia & $\begin{array}{l}\text { No epithelial } \\
\text { defects }\end{array}$ & $\begin{array}{l}\text { No oxyntic } \\
\text { atrophy }\end{array}$ & No metaplasia \\
\hline $\mathbf{1}$ & $\begin{array}{l}\text { Mild patchy or } \\
\text { multifocal } \\
\text { islands }\end{array}$ & $\begin{array}{l}\text { Mild elongation } \\
\text { of mucosa }\end{array}$ & $\begin{array}{l}\text { Tattered } \\
\text { epithelial } \\
\text { surface }\end{array}$ & $\begin{array}{l}\text { Decreased chief } \\
\text { cells; parietal } \\
\text { cells intact }\end{array}$ & $\begin{array}{l}<50 \% \\
\text { replacement of } \\
\text { oxyntic mucosa } \\
\text { by antralized } \\
\text { glands }\end{array}$ \\
\hline $\mathbf{2}$ & $\begin{array}{l}\text { Moderate } \\
\text { coalescing } \\
\text { infiltrate }\end{array}$ & $\begin{array}{l}\text { Increased } \\
\text { surface } \\
\text { epithelium 2X } \\
\text { normal length }\end{array}$ & $\begin{array}{l}\text { Attenuated } \\
\text { epithelial } \\
\text { surface }\end{array}$ & $\begin{array}{l}\text { Few or no chief } \\
\text { cells; parietal } \\
\text { cells intact }\end{array}$ & $\begin{array}{l}\text { >50\% } \\
\text { replacement of } \\
\text { oxyntic mucosa } \\
\text { by antralized } \\
\text { glands }\end{array}$ \\
\hline $\mathbf{3}$ & $\begin{array}{l}\text { Moderate to } \\
\text { severe sheets in } \\
\text { mucosa and/or } \\
\text { submucosa }\end{array}$ & $\begin{array}{l}\text { Increased } \\
\text { surface } \\
\text { epithelium } 3 \mathrm{X} \\
\text { normal length }\end{array}$ & $\begin{array}{l}\text { Inapparent } \\
\text { surface } \\
\text { epithelium }\end{array}$ & $\begin{array}{l}\text { No remaining } \\
\text { chief cells; } \text { loss } \\
\text { of parietal cells }\end{array}$ & $\begin{array}{l}\text { Near complete } \\
\text { replacement of } \\
\text { glands by } \\
\text { antralized } \\
\text { mucosa }\end{array}$ \\
\hline $\mathbf{4}$ & $\begin{array}{l}\text { Severe florid } \\
\text { inflammation } \\
\text { into muscularis }\end{array}$ & $\begin{array}{l}\text { Increased } \\
\text { surface } \\
\text { epithelium } 4 \mathrm{X} \\
\text { normal length } \\
+/- \text { dysplasia }\end{array}$ & $\begin{array}{l}\text { Mucosal } \\
\text { erosions of } \\
\text { surface } \\
\text { epithelium }\end{array}$ & $\begin{array}{l}\text { No chief cells } \\
\text { and few or no } \\
\text { parietal cells } \\
\text { remaining }\end{array}$ & $\begin{array}{l}\text { Total } \\
\text { replacement of } \\
\text { glands by } \\
\text { antralized } \\
\text { muscosa }\end{array}$ \\
\hline
\end{tabular}


1. Hooi JKY, Lai WY, Ng WK, Suen MMY, Underwood FE, Tanyingoh D, Malfertheiner P, Graham DY, Wong VWS, Wu JCY, Chan FKL, Sung JJY, Kaplan GG, Ng SC. 2017. Global Prevalence of Helicobacter pylori Infection: Systematic Review and MetaAnalysis. Gastroenterology 153:420-429.

2. Cover TL, Blaser MJ. 2009. Helicobacter pylori in health and disease. Gastroenterology 136:1863-73.

3. Eaton KA, Brooks CL, Morgan DR, Krakowka S. 1991. Essential role of urease in pathogenesis of gastritis induced by Helicobacter pylori in gnotobiotic piglets. Infect Immun 59:2470-5.

4. Nakamura H, Yoshiyama H, Takeuchi H, Mizote T, Okita K, Nakazawa T. 1998. Urease plays an important role in the chemotactic motility of Helicobacter pylori in a viscous environment. Infect Immun 66:4832-7.

5. Tsuda M, Karita M, Mizote T, Morshed MG, Okita K, Nakazawa T. 1994. Essential role of Helicobacter pylori urease in gastric colonization: definite proof using a ureasenegative mutant constructed by gene replacement. Eur J Gastroenterol Hepatol 6 Suppl 1:S49-52.

6. Tsuda M, Karita M, Morshed MG, Okita K, Nakazawa T. 1994. A urease-negative mutant of Helicobacter pylori constructed by allelic exchange mutagenesis lacks the ability to colonize the nude mouse stomach. Infect Immun 62:3586-9.

7. Eaton KA, Suerbaum S, Josenhans C, Krakowka S. 1996. Colonization of gnotobiotic piglets by Helicobacter pylori deficient in two flagellin genes. Infect Immun 64:2445-8.

8. Howitt MR, Lee JY, Lertsethtakarn P, Vogelmann R, Joubert LM, Ottemann KM, Amieva MR. 2011. ChePep controls Helicobacter pylori Infection of the gastric glands and chemotaxis in the Epsilonproteobacteria. MBio 2.

9. Rolig AS, Shanks J, Carter JE, Ottemann KM. 2012. Helicobacter pylori requires TlpDdriven chemotaxis to proliferate in the antrum. Infect Immun 80:3713-20.

10. Terry K, Williams SM, Connolly L, Ottemann KM. 2005. Chemotaxis plays multiple roles during Helicobacter pylori animal infection. Infect Immun 73:803-11.

11. Schreiber S, Konradt M, Groll C, Scheid P, Hanauer G, Werling HO, Josenhans C, Suerbaum S. 2004. The spatial orientation of Helicobacter pylori in the gastric mucus. Proc Natl Acad Sci U S A 101:5024-9.

12. Amieva MR, Salama NR, Tompkins LS, Falkow S. 2002. Helicobacter pylori enter and survive within multivesicular vacuoles of epithelial cells. Cell Microbiol 4:677-90.

13. Chu YT, Wang YH, Wu JJ, Lei HY. 2010. Invasion and multiplication of Helicobacter pylori in gastric epithelial cells and implications for antibiotic resistance. Infect Immun 78:4157-65.

14. Kwok T, Backert S, Schwarz H, Berger J, Meyer TF. 2002. Specific entry of Helicobacter pylori into cultured gastric epithelial cells via a zipper-like mechanism. Infect Immun 70:2108-20.

15. Tan S, Tompkins LS, Amieva MR. 2009. Helicobacter pylori usurps cell polarity to turn the cell surface into a replicative niche. PLoS Pathog 5:e1000407.

16. Sycuro LK, Pincus Z, Gutierrez KD, Biboy J, Stern CA, Vollmer W, Salama NR. 2010. Peptidoglycan crosslinking relaxation promotes Helicobacter pylori's helical shape and stomach colonization. Cell 141:822-33. 
17. Sycuro LK, Wyckoff TJ, Biboy J, Born P, Pincus Z, Vollmer W, Salama NR. 2012. Multiple peptidoglycan modification networks modulate Helicobacter pylori's cell shape, motility, and colonization potential. PLoS Pathog 8:e1002603.

18. An DR, Kim HS, Kim J, Im HN, Yoon HJ, Yoon JY, Jang JY, Hesek D, Lee M, Mobashery S, Kim SJ, Lee BI, Suh SW. 2015. Structure of Csd3 from Helicobacter pylori, a cell shape-determining metallopeptidase. Acta Crystallogr D Biol Crystallogr 71:675-86.

19. Bonis M, Ecobichon C, Guadagnini S, Prevost MC, Boneca IG. 2010. A M23B family metallopeptidase of Helicobacter pylori required for cell shape, pole formation and virulence. Mol Microbiol 78:809-19.

20. Kim HS, Im HN, An DR, Yoon JY, Jang JY, Mobashery S, Hesek D, Lee M, Yoo J, Cui M, Choi S, Kim C, Lee NK, Kim SJ, Kim JY, Bang G, Han BW, Lee BI, Yoon HJ, Suh SW. 2015. The Cell Shape-determining Csd6 Protein from Helicobacter pylori Constitutes a New Family of L,D-Carboxypeptidase. J Biol Chem 290:25103-17.

21. Kim HS, Kim J, Im HN, An DR, Lee M, Hesek D, Mobashery S, Kim JY, Cho K, Yoon HJ, Han BW, Lee BI, Suh SW. 2014. Structural basis for the recognition of muramyltripeptide by Helicobacter pylori Csd4, a D,L-carboxypeptidase controlling the helical cell shape. Acta Crystallogr D Biol Crystallogr 70:2800-12.

22. Sycuro LK, Rule CS, Petersen TW, Wyckoff TJ, Sessler T, Nagarkar DB, Khalid F, Pincus Z, Biboy J, Vollmer W, Salama NR. 2013. Flow cytometry-based enrichment for cell shape mutants identifies multiple genes that influence Helicobacter pylori morphology. Mol Microbiol 90:869-83.

23. Martinez LE, Hardcastle JM, Wang J, Pincus Z, Tsang J, Hoover TR, Bansil R, Salama NR. 2016. Helicobacter pylori strains vary cell shape and flagellum number to maintain robust motility in viscous environments. Mol Microbiol 99:88-110.

24. Atherton JC. 2006. The pathogenesis of Helicobacter pylori-induced gastro-duodenal diseases. Annu Rev Pathol 1:63-96.

25. Wroblewski LE, Peek RM, Jr. 2013. Helicobacter pylori in gastric carcinogenesis: mechanisms. Gastroenterol Clin North Am 42:285-98.

26. Blaser MJ, Atherton JC. 2004. Helicobacter pylori persistence: biology and disease. J Clin Invest 113:321-33.

27. Uemura N, Okamoto S, Yamamoto S, Matsumura N, Yamaguchi S, Yamakido M, Taniyama K, Sasaki N, Schlemper RJ. 2001. Helicobacter pylori infection and the development of gastric cancer. N Engl J Med 345:784-9.

28. Akada JK, Ogura K, Dailidiene D, Dailide G, Cheverud JM, Berg DE. 2003. Helicobacter pylori tissue tropism: mouse-colonizing strains can target different gastric niches. Microbiology 149:1901-9.

29. Ferrero RL, Thiberge JM, Huerre M, Labigne A. 1998. Immune responses of specificpathogen-free mice to chronic Helicobacter pylori (strain SS1) infection. Infect Immun 66:1349-55.

30. Sakagami T, Dixon M, O'Rourke J, Howlett R, Alderuccio F, Vella J, Shimoyama T, Lee A. 1996. Atrophic gastric changes in both Helicobacter felis and Helicobacter pylori infected mice are host dependent and separate from antral gastritis. Gut 39:639-48.

31. Arnold IC, Lee JY, Amieva MR, Roers A, Flavell RA, Sparwasser T, Muller A. 2011. Tolerance rather than immunity protects from Helicobacter pylori-induced gastric preneoplasia. Gastroenterology 140:199-209. 
32. Sigal M, Rothenberg ME, Logan CY, Lee JY, Honaker RW, Cooper RL, Passarelli B, Camorlinga M, Bouley DM, Alvarez G, Nusse R, Torres J, Amieva MR. 2015. Colonization of the Gastric Glands. Gastroenterology 148:1392-404 e21.

33. Langford ML, Zabaleta J, Ochoa AC, Testerman TL, McGee DJ. 2006. In vitro and in vivo complementation of the Helicobacter pylori arginase mutant using an intergenic chromosomal site. Helicobacter 11:477-93.

34. Rogers AB. 2012. Histologic scoring of gastritis and gastric cancer in mouse models. Methods Mol Biol 921:189-203.

35. Sayi A, Kohler E, Hitzler I, Arnold I, Schwendener R, Rehrauer H, Muller A. 2009. The CD4+ T cell-mediated IFN-gamma response to Helicobacter infection is essential for clearance and determines gastric cancer risk. J Immunol 182:7085-101.

36. Montecucco C, Rappuoli R. 2001. Living dangerously: how Helicobacter pylori survives in the human stomach. Nat Rev Mol Cell Biol 2:457-66.

37. Goldenring JR, Nomura S. 2006. Differentiation of the gastric mucosa III. Animal models of oxyntic atrophy and metaplasia. Am J Physiol Gastrointest Liver Physiol 291:G999-1004.

38. Velin D, Favre L, Bernasconi E, Bachmann D, Pythoud C, Saiji E, Bouzourene H, Michetti P. 2009. Interleukin-17 is a critical mediator of vaccine-induced reduction of Helicobacter infection in the mouse model. Gastroenterology 136:2237-2246 e1.

39. Boncristiano M, Paccani SR, Barone S, Ulivieri C, Patrussi L, Ilver D, Amedei A, D'Elios MM, Telford JL, Baldari CT. 2003. The Helicobacter pylori vacuolating toxin inhibits T cell activation by two independent mechanisms. J Exp Med 198:1887-97.

40. Gebert B, Fischer W, Weiss E, Hoffmann R, Haas R. 2003. Helicobacter pylori vacuolating cytotoxin inhibits T lymphocyte activation. Science 301:1099-102.

41. Sundrud MS, Torres VJ, Unutmaz D, Cover TL. 2004. Inhibition of primary human T cell proliferation by Helicobacter pylori vacuolating toxin (VacA) is independent of VacA effects on IL-2 secretion. Proc Natl Acad Sci U S A 101:7727-32.

42. Frirdich E, Biboy J, Adams C, Lee J, Ellermeier J, Gielda LD, Dirita VJ, Girardin SE, Vollmer W, Gaynor EC. 2012. Peptidoglycan-modifying enzyme Pgp1 is required for helical cell shape and pathogenicity traits in Campylobacter jejuni. PLoS Pathog 8:e1002602.

43. Frirdich E, Vermeulen J, Biboy J, Soares F, Taveirne ME, Johnson JG, DiRita VJ, Girardin SE, Vollmer W, Gaynor EC. 2014. Peptidoglycan LD-carboxypeptidase Pgp2 influences Campylobacter jejuni helical cell shape and pathogenic properties and provides the substrate for the DL-carboxypeptidase Pgp1. J Biol Chem 289:8007-18.

44. Stahl M, Frirdich E, Vermeulen J, Badayeva Y, Li X, Vallance BA, Gaynor EC. 2016. The Helical Shape of Campylobacter jejuni Promotes In Vivo Pathogenesis by Aiding Transit through Intestinal Mucus and Colonization of Crypts. Infect Immun 84:33993407.

45. Lee A, O'Rourke J, De Ungria MC, Robertson B, Daskalopoulos G, Dixon MF. 1997. A standardized mouse model of Helicobacter pylori infection: introducing the Sydney strain. Gastroenterology 112:1386-97.

46. Wang Y, Roos KP, Taylor DE. 1993. Transformation of Helicobacter pylori by chromosomal metronidazole resistance and by a plasmid with a selectable chloramphenicol resistance marker. J Gen Microbiol 139:2485-93. 
47. Lacayo CI, Pincus Z, VanDuijn MM, Wilson CA, Fletcher DA, Gertler FB, Mogilner A, Theriot JA. 2007. Emergence of large-scale cell morphology and movement from local actin filament growth dynamics. PLoS Biol 5:e233. 


\section{Figure Legends}

Figure 1. Experimental outline. C57BL6/J mice were infected by oral gavage with wild-type (PMSS1), straight rod mutants $(\Delta c s d 6)$, or csd6 complemented H. pylori bacteria, or mockinfected with broth. At the indicated time points, the stomach was removed and one third used to determine bacterial load, one third for pathology evaluation, and one third for bacterial

711 localization within glands. C, corpus; A, antrum; CFU, colony-forming units; PFA,

712 paraformaldehyde; NBF, neutral-buffered formalin; H\&E, hematoxylin and eosin; IHC,

713 immunohistochemistry.

Figure 2. The $H$. pylori straight rod mutant $\Delta c s d 6$ shows early colonization defects wild-type strain, $\Delta c s d 6, c s d 6$ complemented, or broth (mock-infection control). (A) Stomach loads at one day and one week of infection. $* * * P<0.001, * * * * P<0.0001$, Kruskal-Wallis test

719 with Dunn's multiple test correction. (B) Competitive infections between wild-type and $\Delta c s d 6$,

720 or $\operatorname{csd} 6$ complemented and $\Delta c s d 6$, with lines connecting the bacterial load values for each

721 genotype from the same mouse. $* * * P<0.001, * * * * P<0.0001$, Mann-Whitney U test. Dotted

722 line indicates the average limit of detection. Data are from two independent experiments with

$723 \mathrm{n}=10$ mice per group. WT, wildtype; comp, complemented; wpi, week post-infection. 
wild-type H. pylori for one week. Shown are maximum intensity projections of Z-stacks, with blue

730 (DAPI, left panel) staining nuclei and yellow staining H. pylori. Scale bar $=100 \mu \mathrm{m}$. (B - D) Gland

731 analysis for wild-type $H$. pylori (B, same mouse as $\mathbf{A}), \Delta c s d 6(\mathbf{C})$ and $\operatorname{csd} 6$ complemented (D),

732 showing the number of bacteria detected by immunofluorescence within glands along the length

733 of the stomach in microns. Red bars indicate the corpus and blue indicate the antrum. (E) The total

734 number of bacteria in the corpus and antral glands is shown for $n=2-3$ mice per strain, with the

735 CFU per gram of stomach for each mouse indicated on the graph. WT, wildtype; comp, 736 complemented; wpi, week post-infection.

Figure 4. Both wild-type $H$. pylori and the $\Delta c s d 6$ straight rod mutant can expand into the

$\Delta c s d 6$, csd6 complemented, or broth (mock-infection control). (A) Stomach loads at one month

741 and three months post-infection. ns, not significant by Kruskal-Wallis test with Dunn's multiple

742 test correction. Data are from two independent experiments with $\mathrm{n}=15$ mice per group; the limit

743 of detection is shown with a dotted line. (B and C) Thick stomach sections from the one month

744 infections shown in A were stained for H. pylori and the number of bacteria within the glands was

745 quantified along the entire length of the section. For each bacterial strain, a mouse with a "low"

746 CFU load (left panel) and a "high" CFU load (right panel) was analyzed. (B) The total number of

747 bacteria in the corpus and antrum is shown for $\mathrm{n}=2$ mice per bacterial strain, with the CFU per

748 gram of stomach for each mouse indicated on the graph. (C) Gland analysis for wild-type H. pylori,

$749 \Delta c s d 6$ and $\operatorname{csd6}$ complemented strains, showing the number of bacteria within corpus and antral

750 glands along the length of the stomach in microns. Red bars indicate the corpus and blue indicate

751 the antrum. WT, wildtype; comp, complemented; wpi, week post-infection. 
753 Figure 5. The $\Delta c s d 6$ straight rod mutants elicit less immunopathology compared to wild-type

754 and csd6 complemented bacteria. Images of hematoxylin and eosin-stained sections from the

755 three month infection, showing corpus, corpus/antral junction (box), and antral regions of the most

756 severe histopathologic changes in each group. Right panels show higher magnification images

$757(20 \mathrm{x})$ within the enclosed black boxes of 10x images on the left. Arrows point to remaining parietal

758 cells in corpus glands and the asterisks denote sites of infiltrating inflammatory cells. Images are

759 from (A) Mock-infected, (B) wild-type-infected (HAI = 21, 7.8 x10³ CFU/g stomach), (C) $\Delta c s d 6-$

760 infected $\left(\mathrm{HAI}=15,1.2 \times 10^{5} \mathrm{CFU} / \mathrm{g}\right.$ stomach $)$, and $(\mathbf{D}) \operatorname{csd} 6$ complemented-infected $(\mathrm{HAI}=22$,

$7614.0 \times 10^{4} \mathrm{CFU} / \mathrm{g}$ of stomach) mice. WT, wildtype; comp, complemented; HAI, histological activity

762 index. Left panels scale bar $=100 \mu \mathrm{m}$; right panels scale bar $=50 \mu \mathrm{m}$.

764 Figure 6. Chronic $\Delta c s d 6$ mutant infections show significantly less histological activity

765 compared to wild-type and csd6 complemented infections. Thin stomach sections from the mice

766 in Figure 4A were used for a blinded analysis of stomach inflammation and pathology. (A) The

767 total histological activity index (HAI) is provided for mock-infected ("Mock"), wild-type, $\Delta c s d 6$,

768 and the $\operatorname{csd} 6$ complemented strain at one and three months of infection. Mean \pm standard deviations

769 are shown. * $P<0.05$, Kruskal-Wallis test with Dunn's multiple test correction. (B) Plot showing

770 the correlation between wild-type and $\Delta c s d 6$ stomach colonization loads and total HAI. 
Figure S1. Complementation of csd6 restores helical cell shape. (A) Representative phase

distributions acquired for each strain shown in B. No significant difference in side curvature using Kolmogorov-Smirnov statistics of side curvature distributions. Significant differences in side curvature distributions were observed between wild-type and $\Delta c s d 6$, and between $\Delta c s d 6$ and the csd6 complemented strain, where $\mathrm{p}<0.00001$. Data are from two independent experiments.

Figure S2. 3D-visualization of $\boldsymbol{H}$. pylori and bacterial quantitation by volumetric image analysis. (A) Representative 3D image of wild-type PMSS1 bacteria (green), which was fixed in $2 \%$ PFA, embedded in $4 \%$ agarose, and sectioned to generate $200 \mu \mathrm{m}$ thick sections. 3D-images were generated from Z-stacks collected at $63 \mathrm{X}$ (oil-immersion objective) with a Zeiss LSM 780

790 confocal microscope. (B) Volumetric image analysis of bacterial cells fixed in 2\% PFA ( $\mathrm{n}=203)$.

791 Bars indicate the mean. Data are from two independent experiments. 
795 of the antrum of a mouse infected with $\Delta c s d 6(\mathbf{A})$ or $c s d 6$ complemented (B) bacteria. Images are

796 maximum intensity projections of Z-stacks, with blue (DAPI, left panel) staining nuclei and yellow

797 staining H. pylori. Scale bars $=100 \mu \mathrm{m}$. Volumetric analysis for the mouse in $\mathbf{A}$ is found in Figure

$798 \quad 3 C$ and $\mathbf{B}$ is in Figure 3D.

799

$800 \quad$ Figure S4. The $\Delta c s d 6$ mutant results in decreased inflammation and hyperplasia scores at

801 one and three months of infection. Inflammation (A and C) and hyperplasia (B and D) scores in

802 the corpus/antrum (C/A) junction and antrum at one month (A and B) and three months (C and D)

803 of infection ( $\mathrm{n}=9-11$ mice per group). Provided are pathological evaluation scores for all gastric

804 tissue sections analyzed and shown in Fig 5. * $P<0.05, * * P<0.01, * * * P<0.001$, Kruskal-Wallis

805 test with Dunn's multiple test correction. 


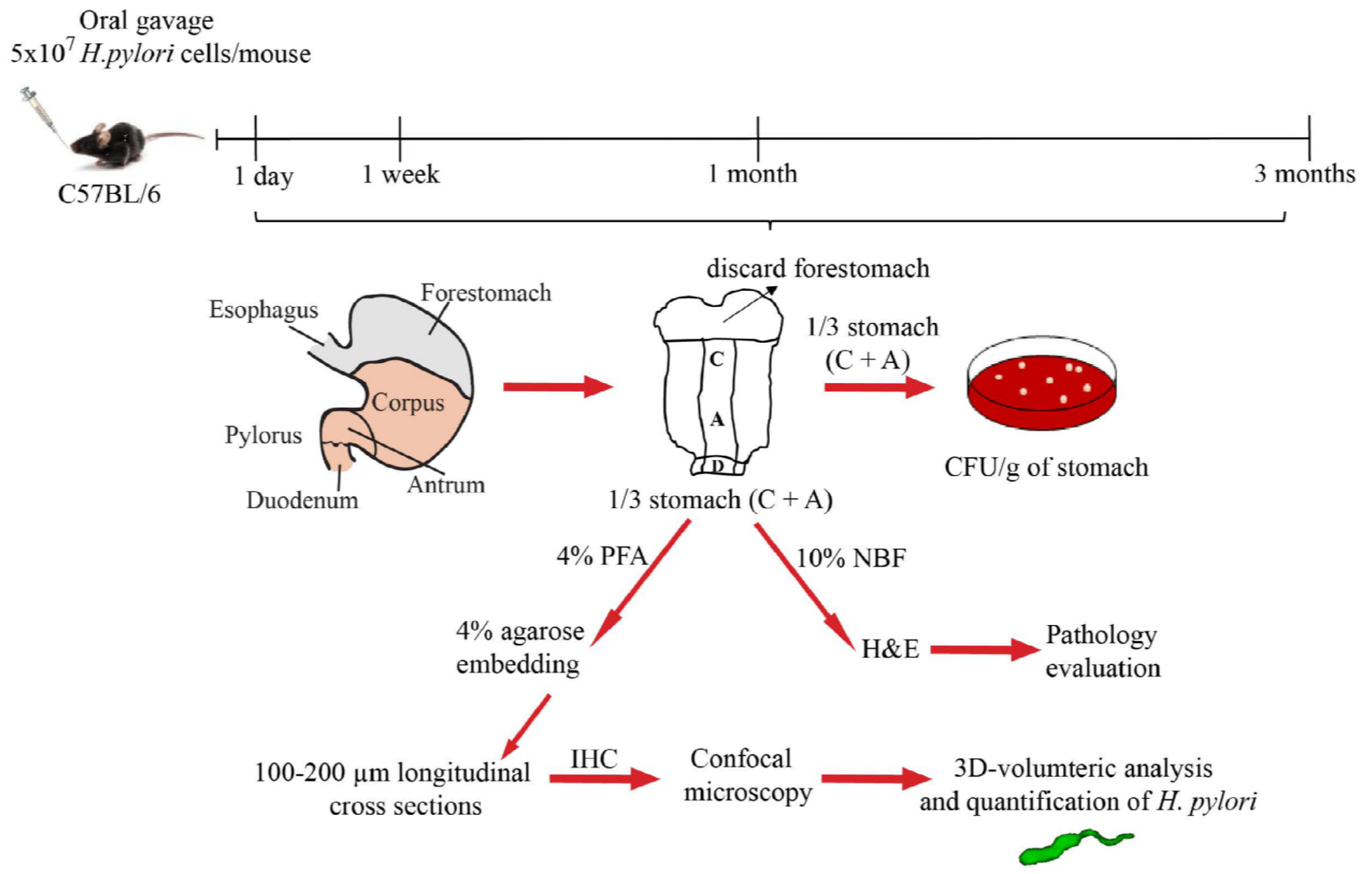


Figure 1. Experimental outline. C57BL6/J mice were infected by oral gavage with wild-type (PMSS1), straight rod mutants $(\Delta c s d 6)$, or $c s d 6$ complemented $H$. pylori bacteria, or mockinfected with broth. At the indicated time points, the stomach was removed and one third used to determine bacterial load, one third for pathology evaluation, and one third for bacterial localization within glands. C, corpus; A, antrum; CFU, colony-forming units; PFA, paraformaldehyde; NBF, neutral-buffered formalin; H\&E, hematoxylin and eosin; IHC, immunohistochemistry. 
A.

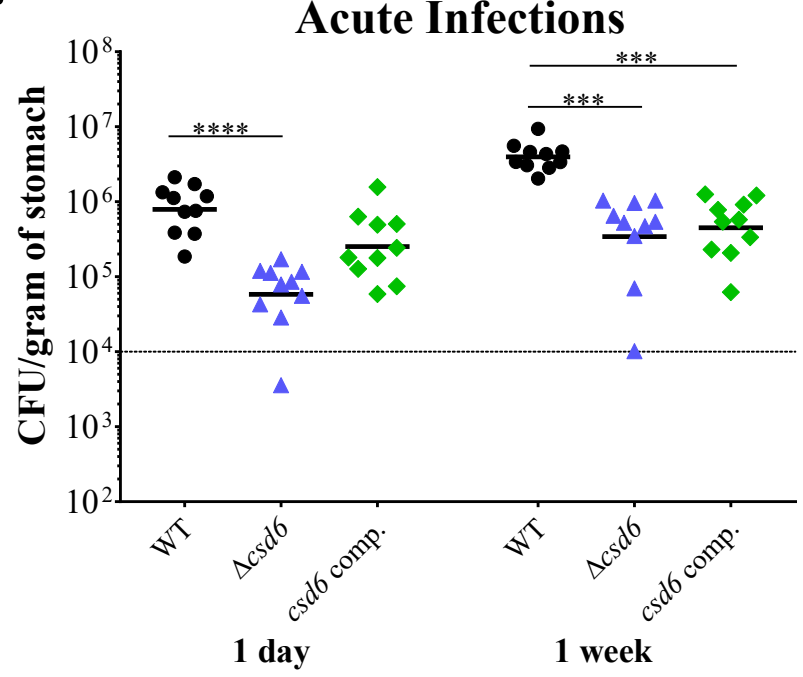

B.

Competitions, 1 wpi

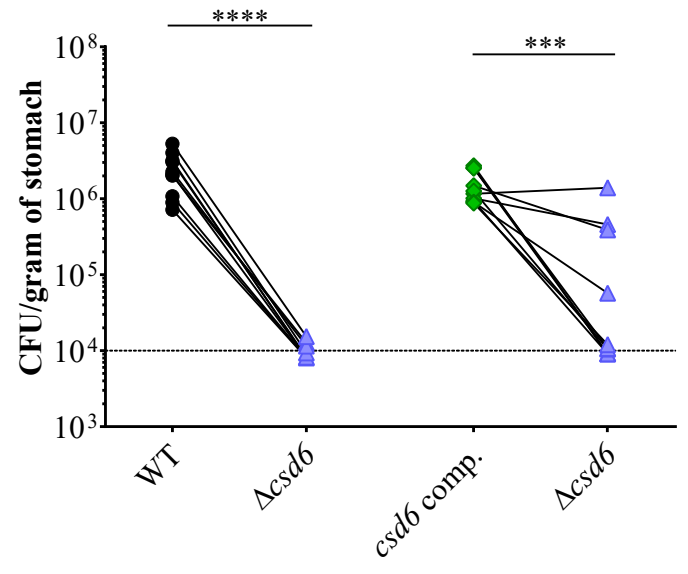




\section{Figure 2. The $H$. pylori straight rod mutant $\Delta c s d 6$ shows early colonization defects}

compared to wild-type bacteria. Single or competitive infections were performed with the wild-type strain, $\Delta c s d 6$, csd6 complemented, or broth (mock-infection control). (A) Stomach loads at one day and one week of infection. $* * * P<0.001, * * * * P<0.0001$, Kruskal-Wallis test with Dunn's multiple test correction. (B) Competitive infections between wild-type and $\Delta c s d 6$, or $c s d 6$ complemented and $\Delta c s d 6$, with lines connecting the bacterial load values for each genotype from the same mouse. ${ }^{* * *} P<0.001, * * * * P<0.0001$, Mann-Whitney U test. Dotted line indicates the average limit of detection. Data are from two independent experiments with $\mathrm{n}=10$ mice per group. WT, wildtype; comp, complemented; wpi, week post-infection. 


\section{A. WT}

B.

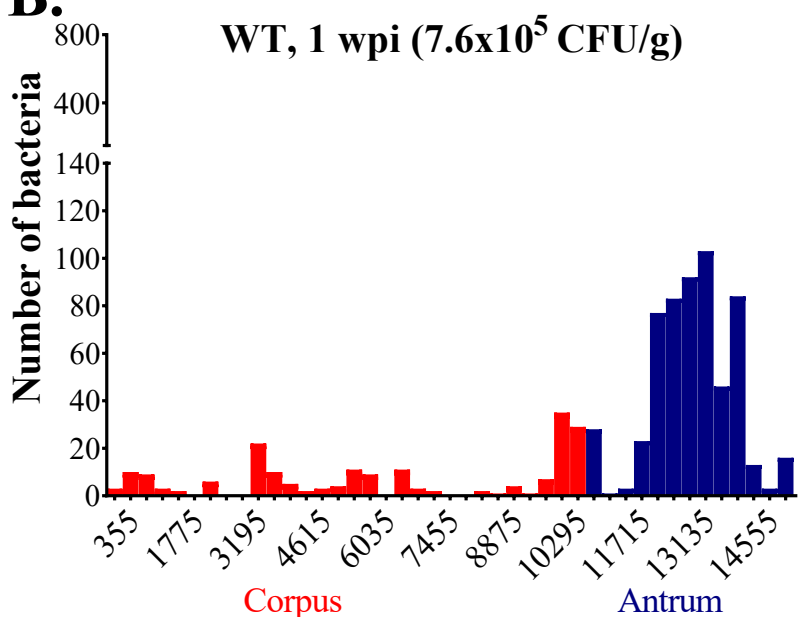

Distance along mucosa $(\mu \mathrm{m})$
${ }^{800} \quad$ csd6 comp., 1 wpi $\left(5.4 \times 10^{5} \mathrm{CFU} / \mathrm{g}\right)$

D.

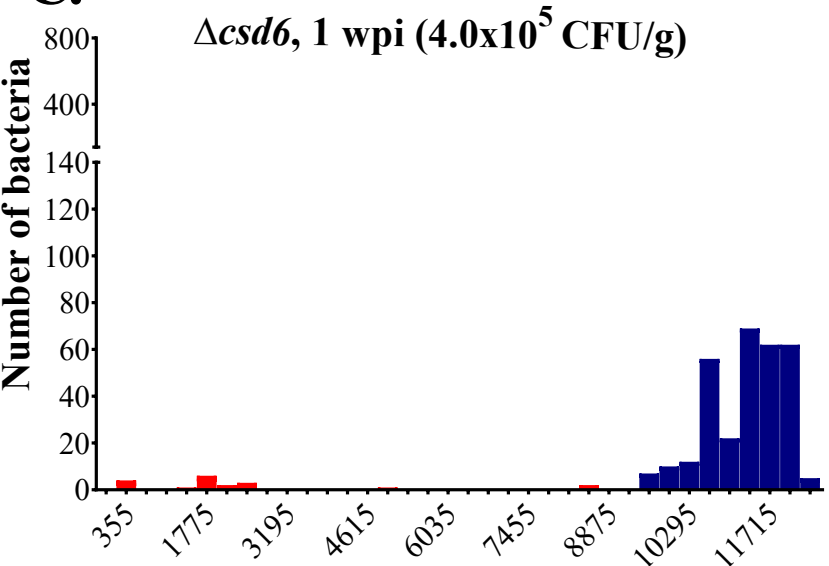

Corpus

Antrum

Distance along mucosa $(\mu \mathrm{m})$

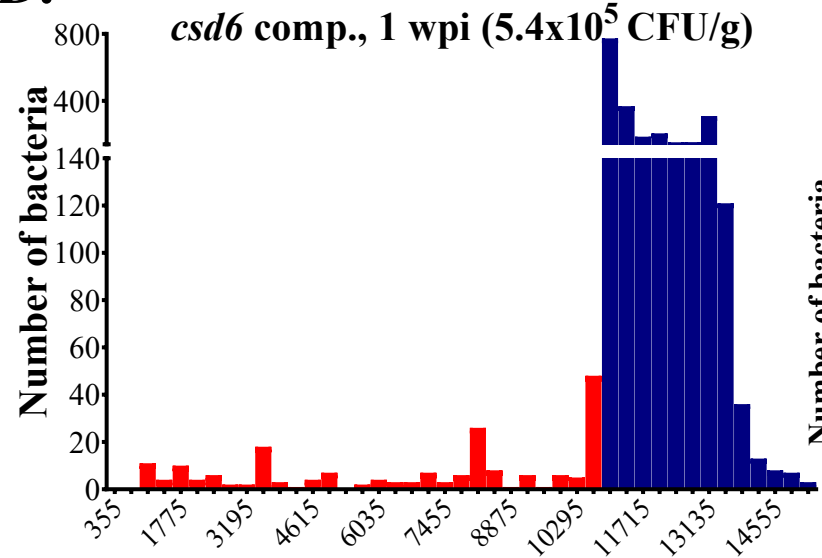

Total Bacteria, 1 wpi

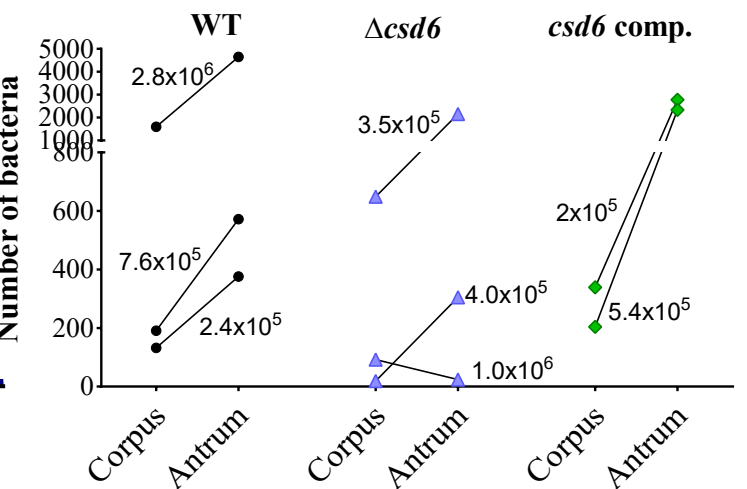

Distance along mucosa $(\mu \mathrm{m})$ 
Figure 3. The $\Delta c s d 6$ straight rod mutant is attenuated in colonizing the corpus and antrum at one week post-infection. Thick stomach sections from the one week infections shown in Figure 2A were stained for H. pylori and the number of bacteria within the glands was quantified along the entire length of the section. (A) Representative images of the antrum of a mouse infected with wild-type $H$. pylori for one week. Shown are maximum intensity projections of Z-stacks, with blue (DAPI, left panel) staining nuclei and yellow staining H. pylori. Scale bar $=100 \mu \mathrm{m}$. (B - D) Gland analysis for wild-type $H$. pylori (B, same mouse as $\mathbf{A}), \Delta c s d 6$ (C) and csd6 complemented (D), showing the number of bacteria detected by immunofluorescence within glands along the length of the stomach in microns. Red bars indicate the corpus and blue indicate the antrum. (E) The total number of bacteria in the corpus and antral glands is shown for $n=2-3$ mice per strain, with the CFU per gram of stomach for each mouse indicated on the graph. WT, wildtype; comp, complemented; wpi, week post-infection. 


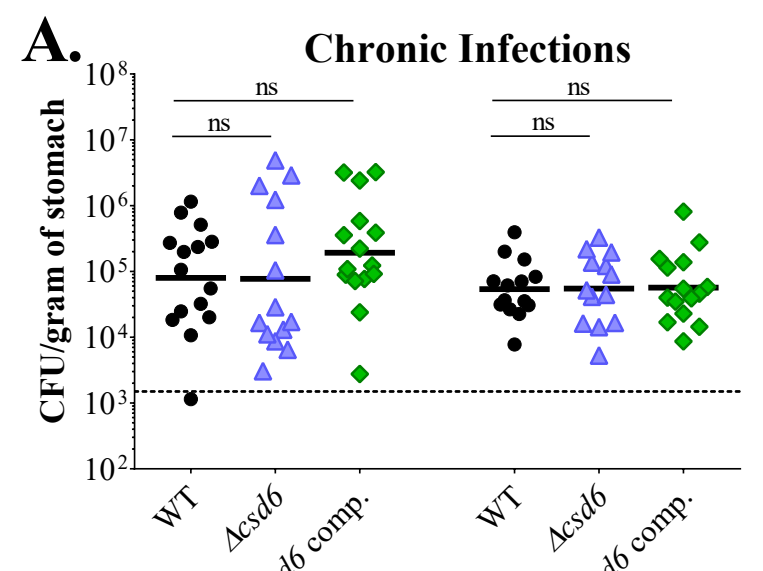

\section{B. Total Bacteria, 4 wpi}

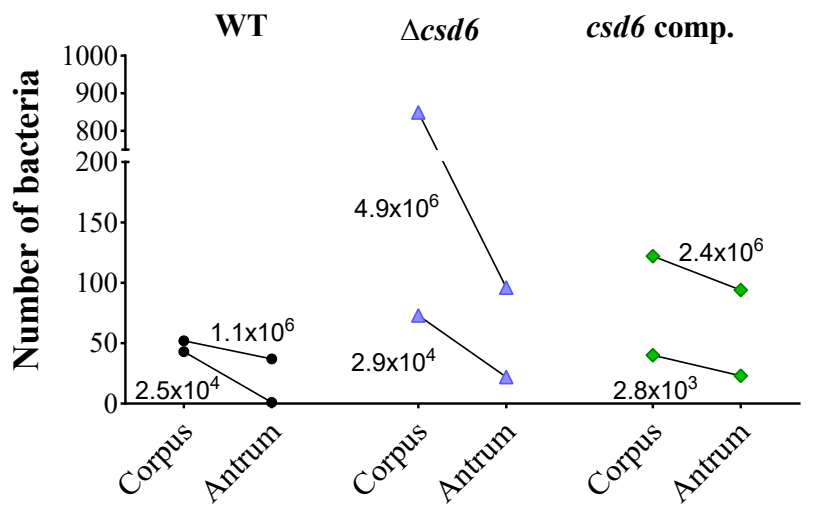

C. 1 month 3 months
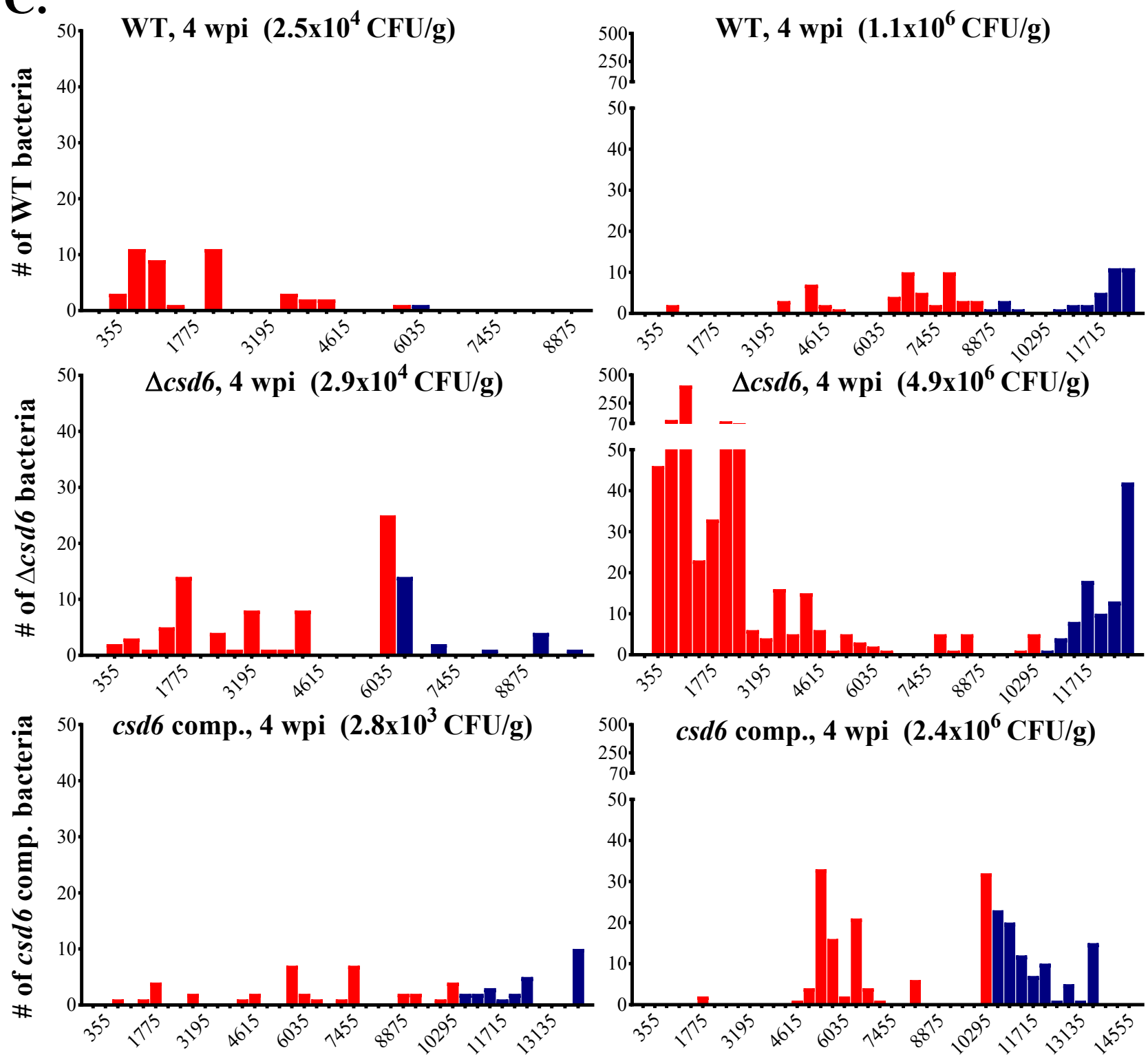

Corpus

Antrum

$\left.\begin{array}{r}500 \\ 250 \\ 70\end{array}\right] \quad$ csd6 comp., 4 wpi $\left(2.4 \times 10^{6} \mathrm{CFU} / \mathrm{g}\right)$

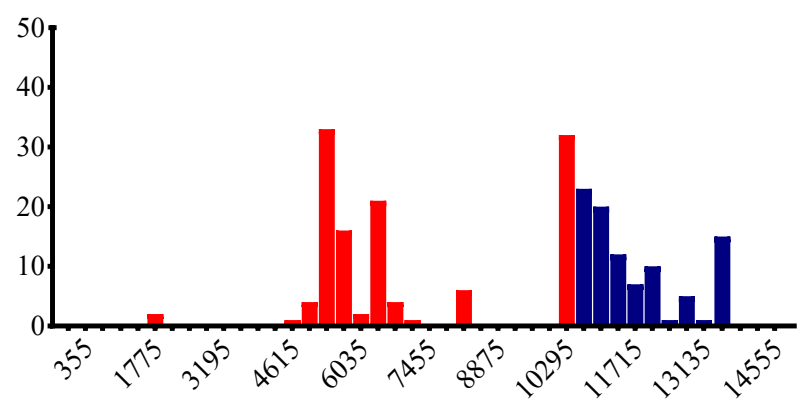

Corpus

Antrum 


\section{Figure 4. Both wild-type $H$. pylori and the $\Delta c s d 6$ straight rod mutant can expand into the} corpus by one month post-infection. Single infections were performed with the wild-type strain, $\Delta c s d 6, c s d 6$ complemented, or broth (mock-infection control). (A) Stomach loads at one month and three months post-infection. ns, not significant by Kruskal-Wallis test with Dunn's multiple test correction. Data are from two independent experiments with $n=15$ mice per group; the limit of detection is shown with a dotted line. (B and C) Thick stomach sections from the one month infections shown in $\mathbf{A}$ were stained for $H$. pylori and the number of bacteria within the glands was quantified along the entire length of the section. For each bacterial strain, a mouse with a "low" CFU load (left panel) and a "high" CFU load (right panel) was analyzed. (B) The total number of bacteria in the corpus and antrum is shown for $n=2$ mice per bacterial strain, with the CFU per gram of stomach for each mouse indicated on the graph. (C) Gland analysis for wild-type H. pylori, $\Delta c s d 6$ and $c s d 6$ complemented strains, showing the number of bacteria within corpus and antral glands along the length of the stomach in microns. Red bars indicate the corpus and blue indicate the antrum. WT, wildtype; comp, complemented; wpi, week post-infection. 


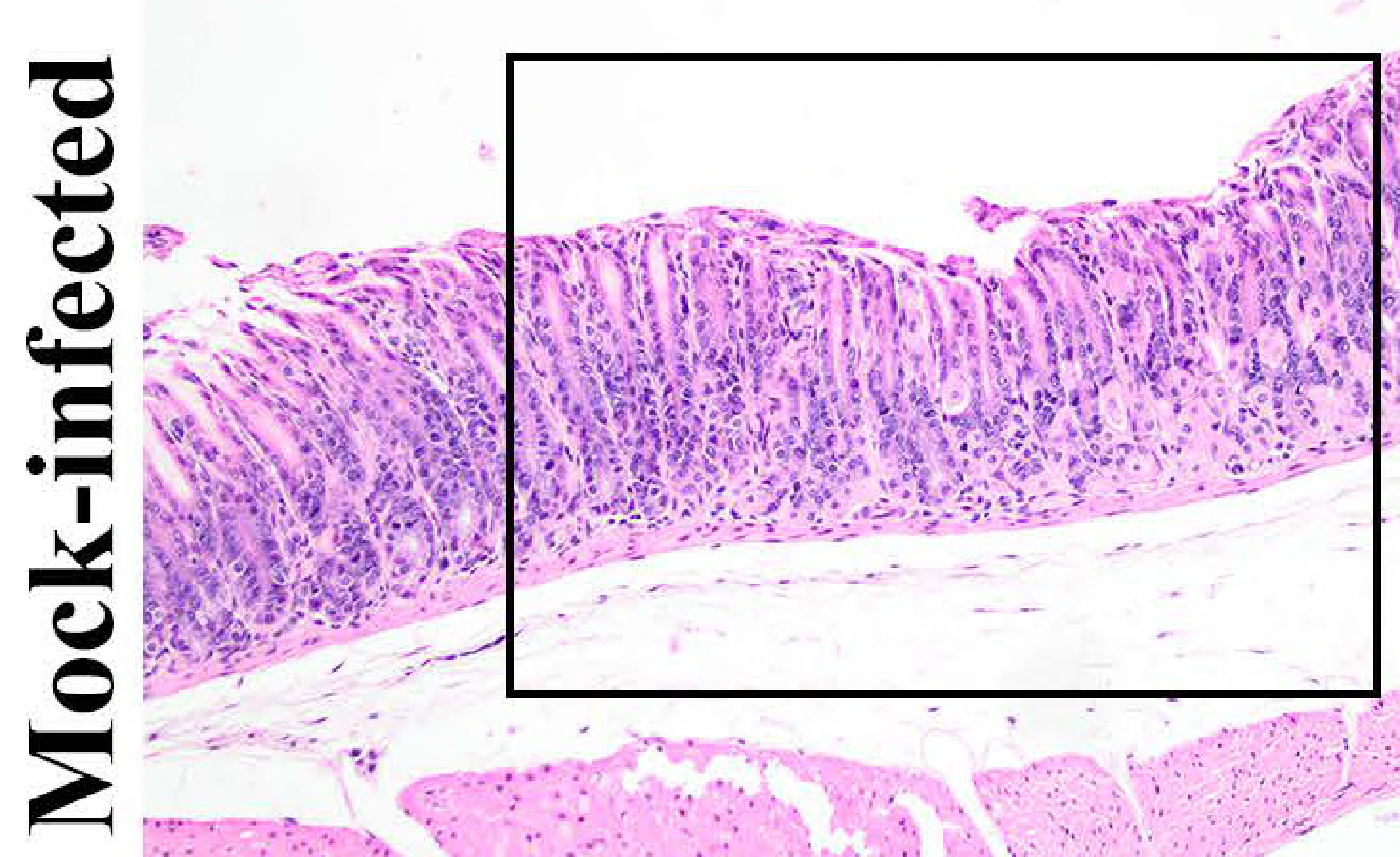

\section{B. Antrum}



Corpus

\section{Antrum}

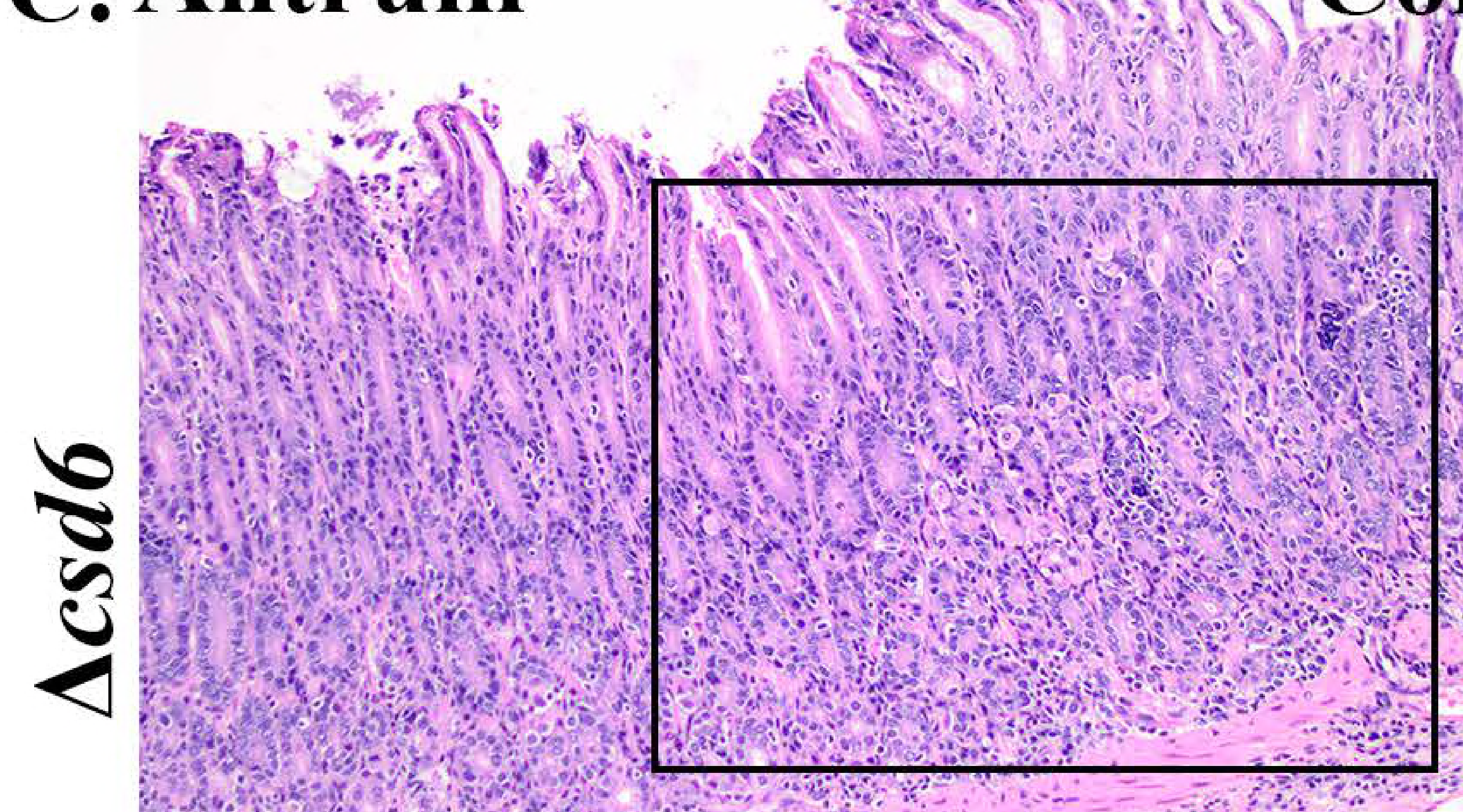

\section{Antrum}

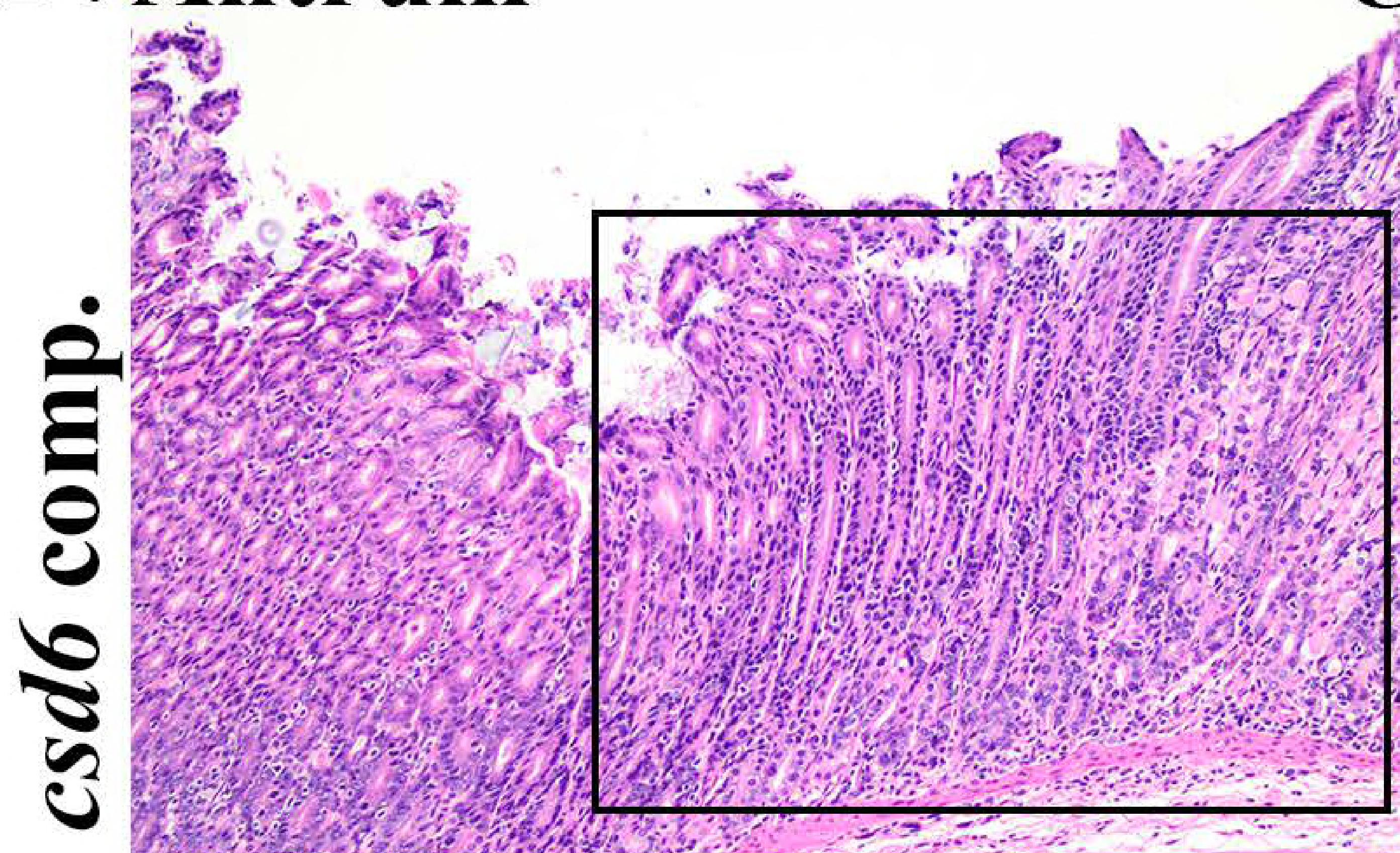

Corpus

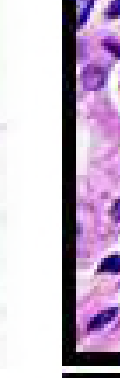
:

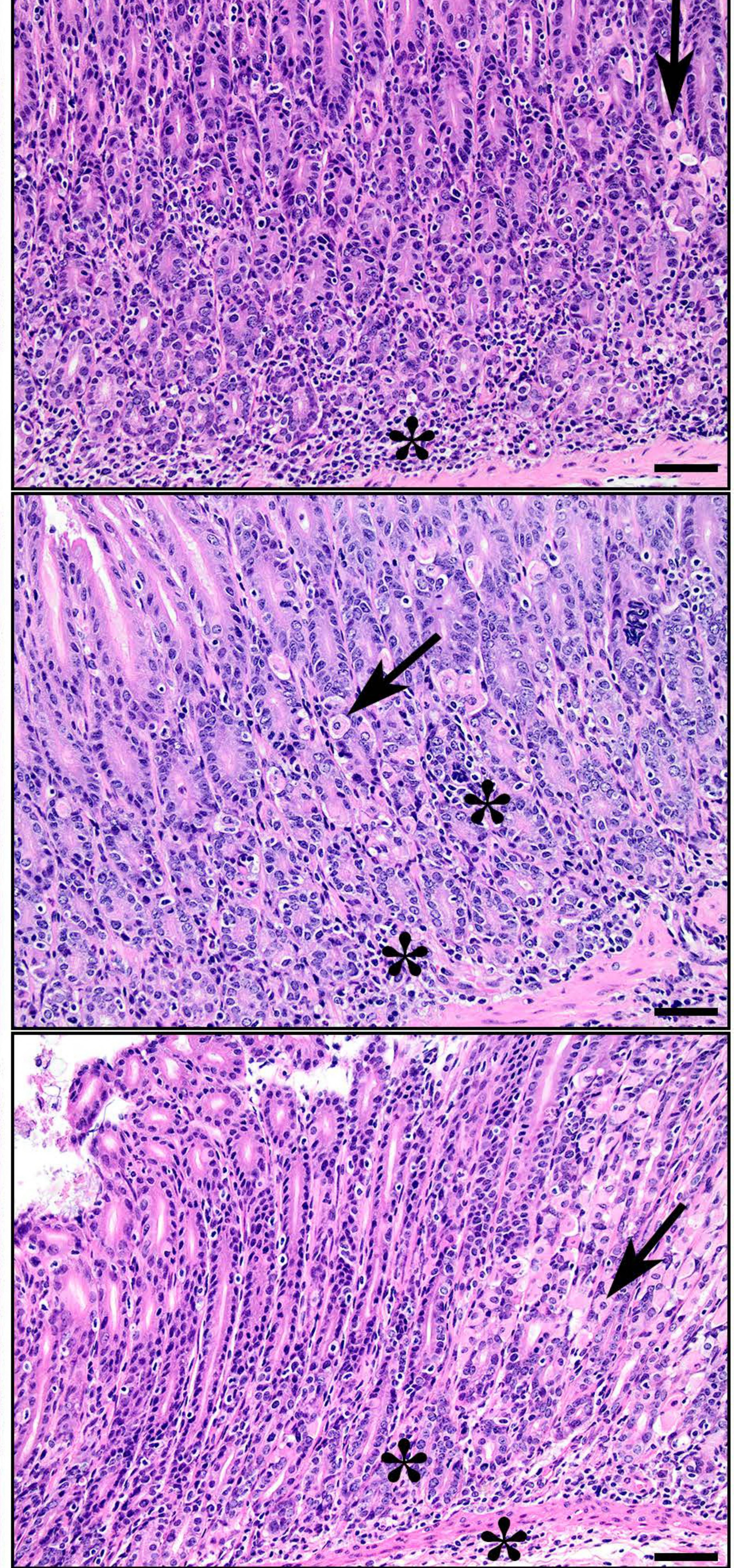


Figure 5. The $\Delta c s d 6$ straight rod mutants elicit less immunopathology compared to wild-type and csd6 complemented bacteria. Images of hematoxylin and eosin-stained sections from the three month infection, showing corpus, corpus/antral junction (box), and antral regions of the most severe histopathologic changes in each group. Right panels show higher magnification images (20x) within the enclosed black boxes of 10x images on the left. Arrows point to remaining parietal cells in corpus glands and the asterisks denote sites of infiltrating inflammatory cells. Images are from (A) Mock-infected, (B) wild-type-infected (HAI = 21, $7.8 \times 10^{3} \mathrm{CFU} / \mathrm{g}$ stomach), (C) $\Delta c s d 6$ infected $\left(\mathrm{HAI}=15,1.2 \times 10^{5} \mathrm{CFU} / \mathrm{g}\right.$ stomach), and (D) $c s d 6$ complemented-infected $(\mathrm{HAI}=22$, $4.0 \times 10^{4} \mathrm{CFU} / \mathrm{g}$ of stomach) mice. WT, wildtype; comp, complemented; HAI, histological activity index. Left panels scale bar $=100 \mu \mathrm{m}$; right panels scale bar $=50 \mu \mathrm{m}$. 


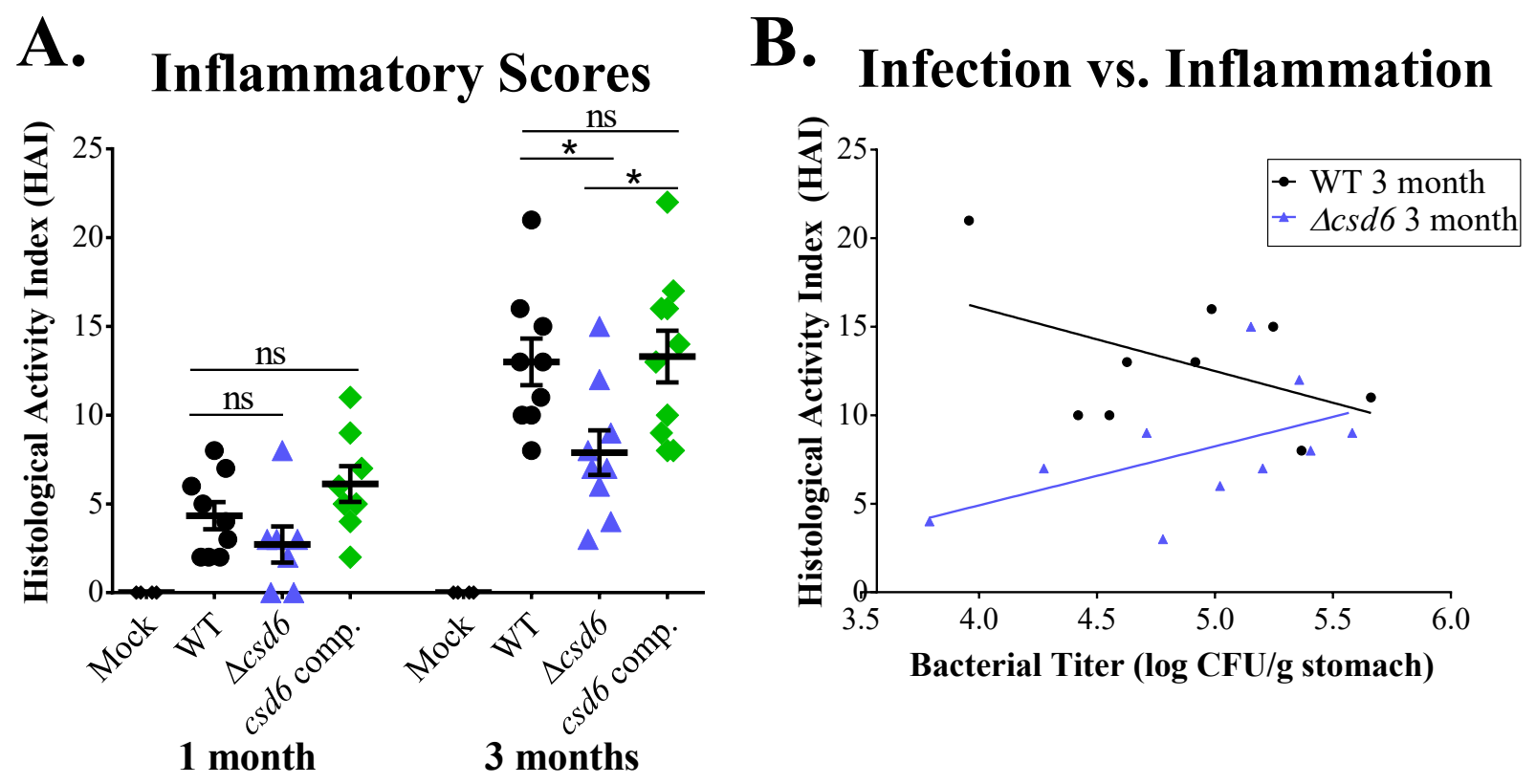


Figure 6. Chronic $\Delta c s d 6$ mutant infections show significantly less histological activity compared to wild-type and $\operatorname{csd} 6$ complemented infections. Thin stomach sections from the mice in Figure 4A were used for a blinded analysis of stomach inflammation and pathology. (A) The total histological activity index (HAI) is provided for mock-infected ("Mock"), wild-type, $\Delta c s d 6$, and the $\operatorname{cs} d 6$ complemented strain at one and three months of infection. Mean \pm standard deviations are shown. * $P<0.05$, Kruskal-Wallis test with Dunn's multiple test correction. (B) Plot showing the correlation between wild-type and $\Delta c s d 6$ stomach colonization loads and total HAI. 
A

PMSS1

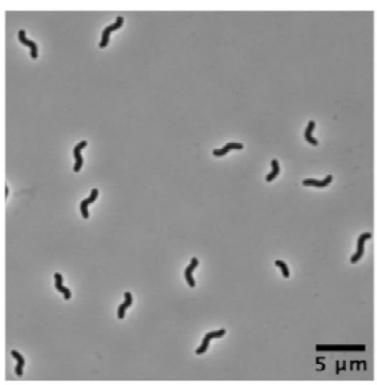

B

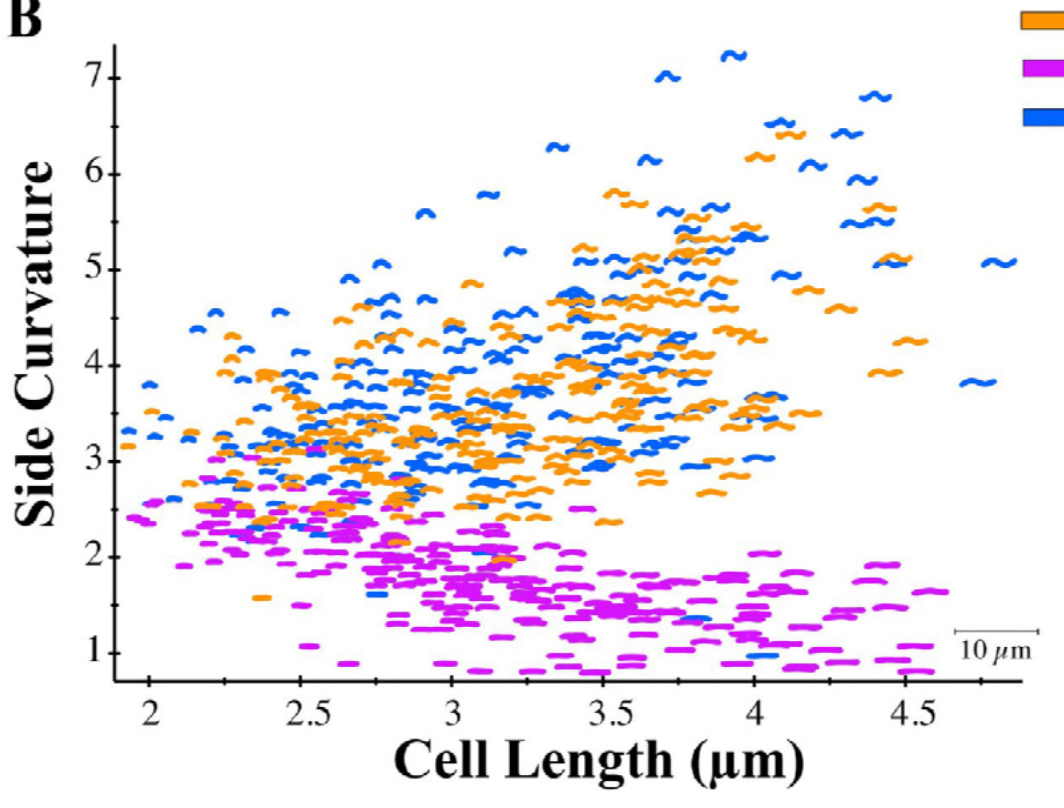

PMSS1 $\Delta c s d 6$

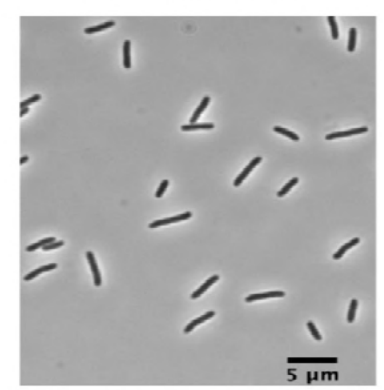

>

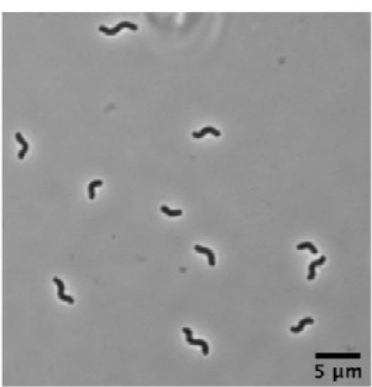

PMSS1

PMSS1 $\Delta \operatorname{csd} d 6$

csd6 comp.

C PMSS1

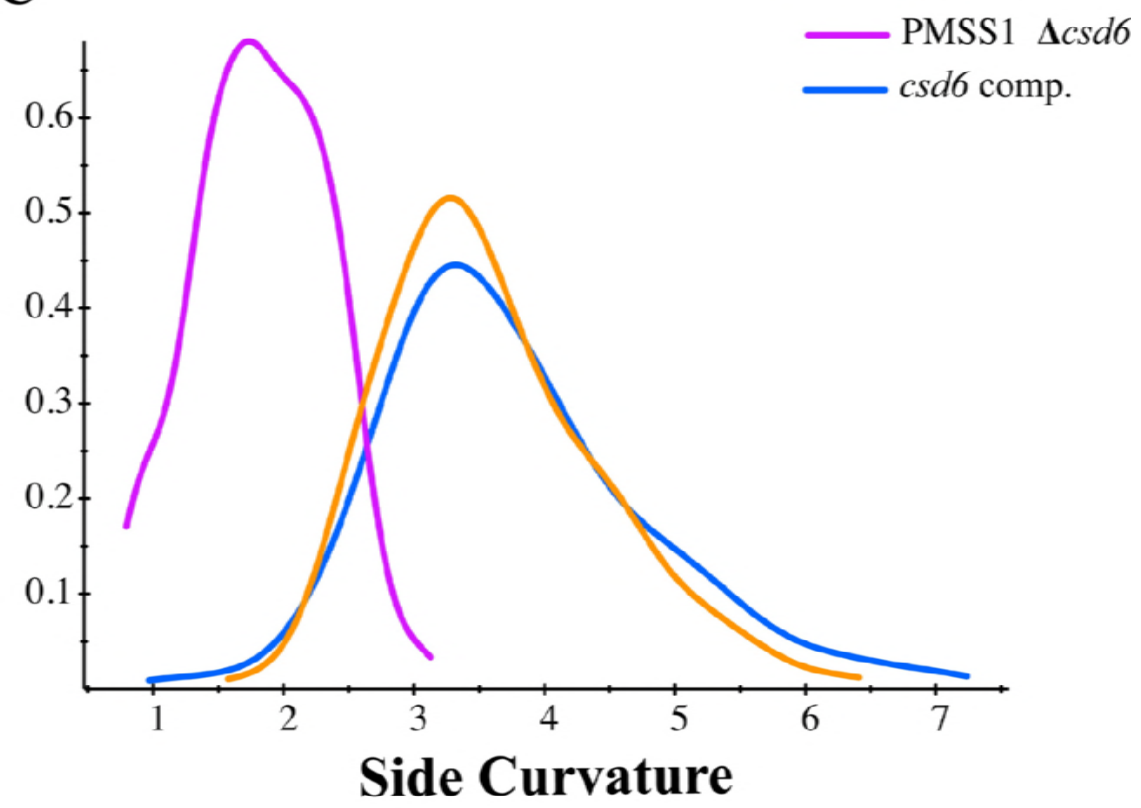


Figure S1. Complementation of csd6 restores helical cell shape. (A) Representative phase contrast images of wild-type PMSS1 bacteria, straight rod $(\Delta c s d \sigma)$, and csd6 complemented bacteria. Images were acquired at $100 \mathrm{X}$ (oil immersion objective). Scale bar $=5 \mu \mathrm{m}$. (B) Side curvature vs. cell length $(\mu \mathrm{m})$ for individual bacterial cells imaged using phase contrast microscopy of wild-type PMSS1 (orange, $\mathrm{n}=218$ ), $\Delta c s d 6$ (magenta, $\mathrm{n}=230$ ), and the $\operatorname{csd6}$ complemented strain (blue, $n=212$ ). (C) Smooth histograms summarizing the side curvature distributions acquired for each strain shown in B. No significant difference in side curvature distributions were observed between wild-type and the $c s d 6$ complemented strain $(p=0.64078)$ using Kolmogorov-Smirnov statistics of side curvature distributions. Significant differences in side curvature distributions were observed between wild-type and $\Delta c s d 6$, and between $\Delta c s d 6$ and the $\operatorname{cs} d 6$ complemented strain, where $\mathrm{p}<0.00001$. Data are from two independent experiments. 
A.

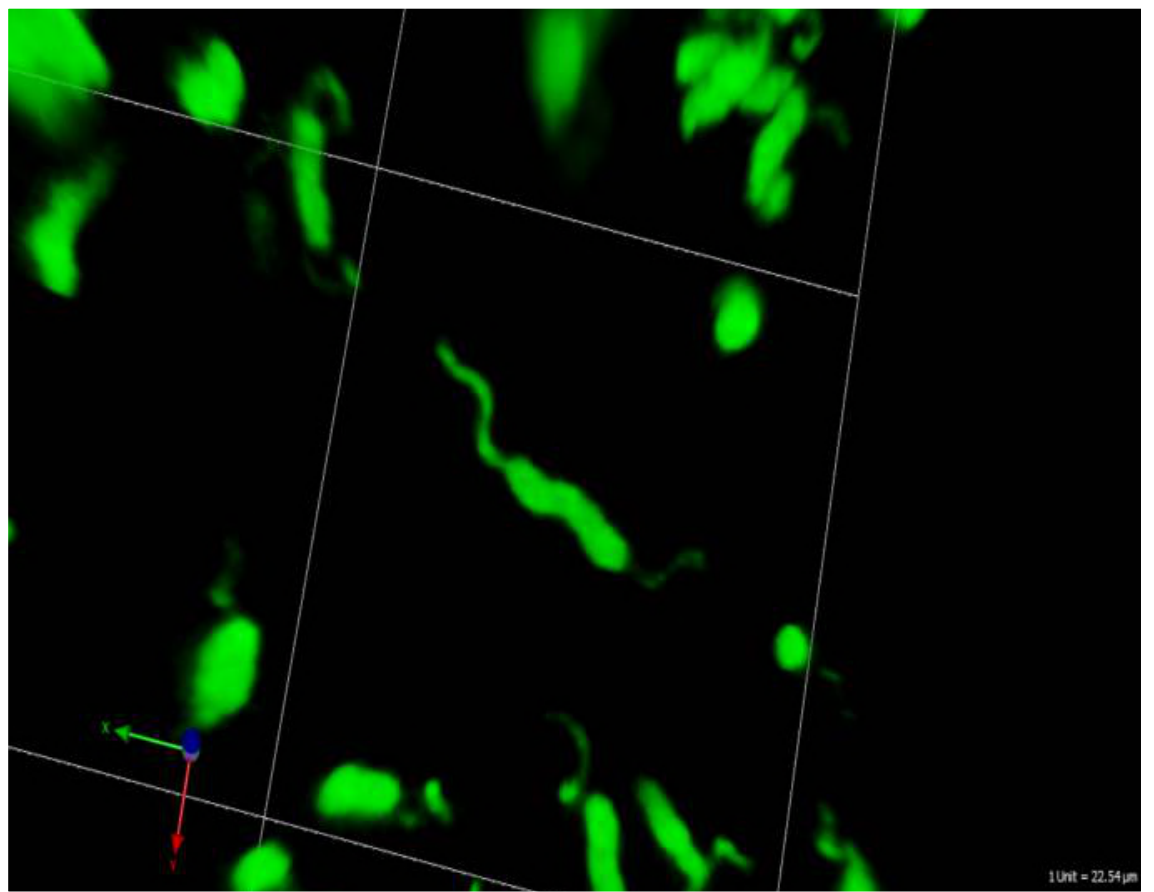

B.

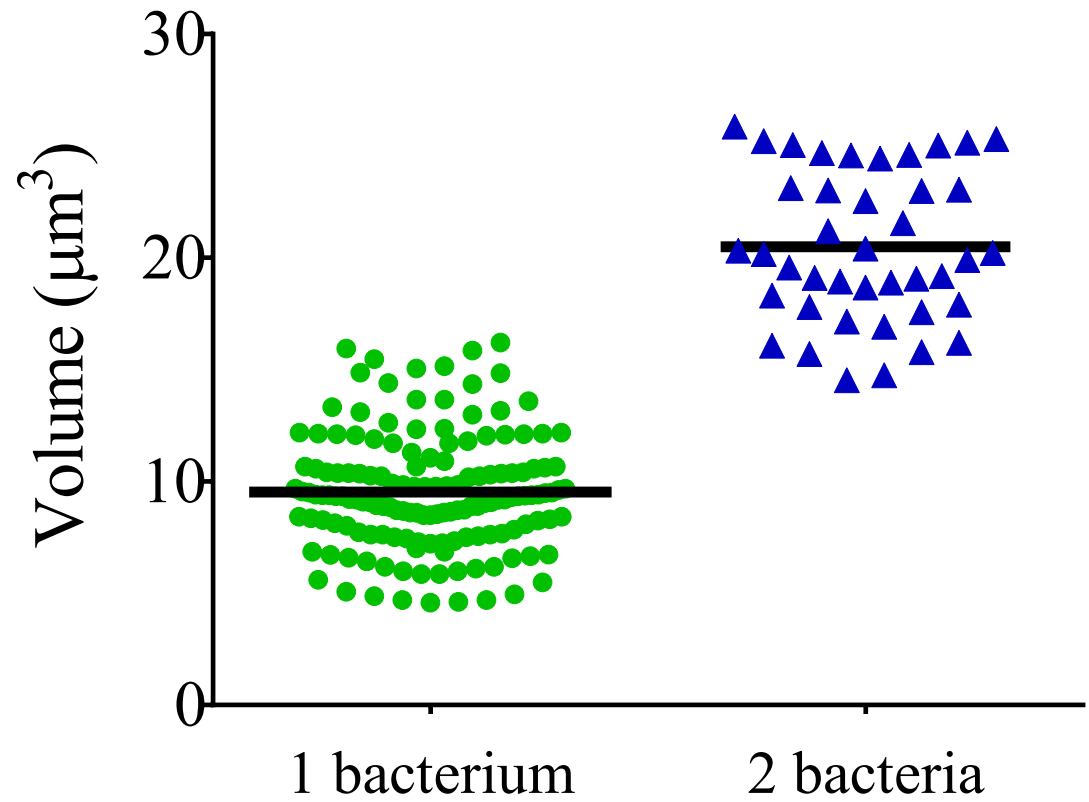


Figure S2. 3D-visualization of $\boldsymbol{H}$. pylori and bacterial quantitation by volumetric image analysis. (A) Representative 3D image of wild-type PMSS1 bacteria (green), which was fixed in $2 \%$ PFA, embedded in 4\% agarose, and sectioned to generate $200 \mu \mathrm{m}$ thick sections. 3D-images were generated from Z-stacks collected at $63 \mathrm{X}$ (oil-immersion objective) with a Zeiss LSM 780 confocal microscope. (B) Volumetric image analysis of bacterial cells fixed in $2 \%$ PFA ( $n=203)$. Bars indicate the mean. Data are from two independent experiments. 


\section{A. $\Delta c s d 6$}

\section{B. csd6 comp. . .}
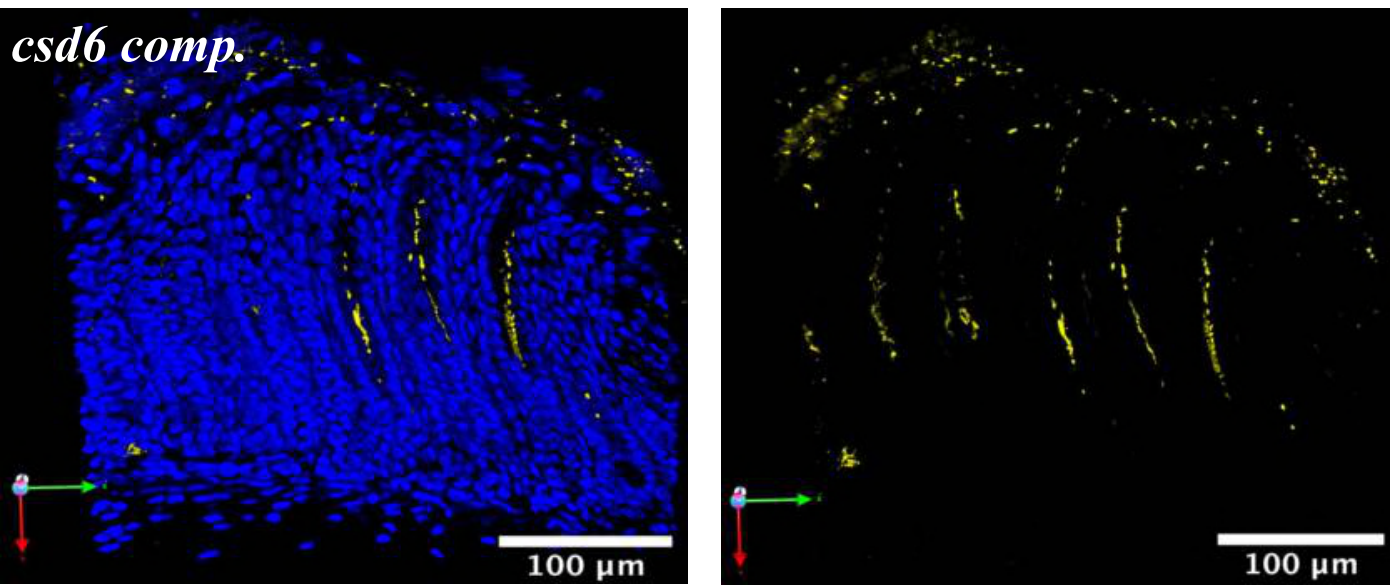
Figure S3. Visualization of bacteria within gastric glands. Thick stomach sections from the one week infections shown in Figure 2A were stained for $H$. pylori. Shown are representative images of the antrum of a mouse infected with $\Delta c s d 6(\mathbf{A})$ or $\operatorname{csd} 6$ complemented (B) bacteria. Images are maximum intensity projections of Z-stacks, with blue (DAPI, left panel) staining nuclei and yellow staining H. pylori. Scale bars $=100 \mu \mathrm{m}$. Volumetric analysis for the mouse in $\mathbf{A}$ is found in Figure 3C and $\mathbf{B}$ is in Figure 3D. 


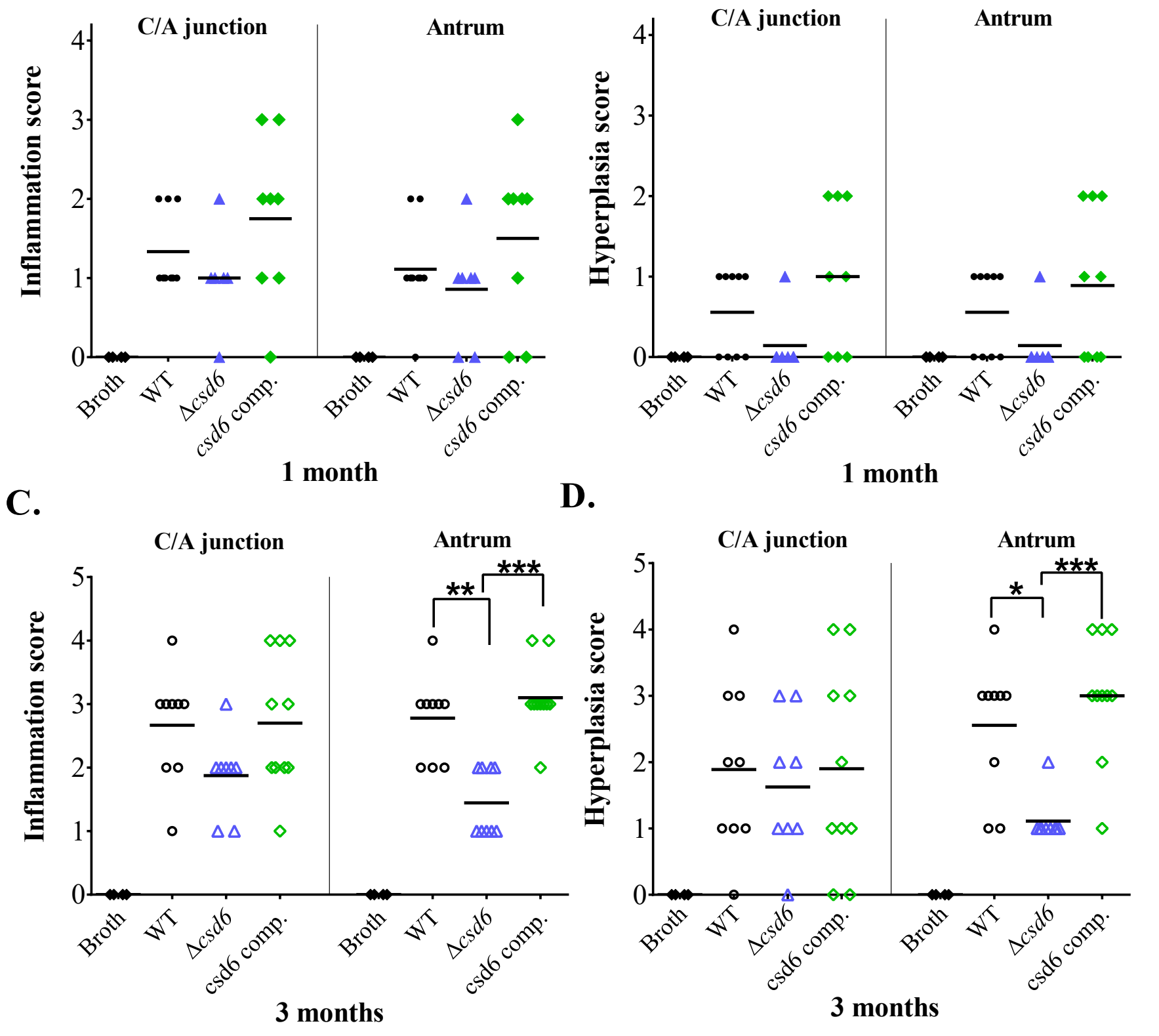


Figure S4. The $\Delta c s d 6$ mutant results in decreased inflammation and hyperplasia scores at one and three months of infection. Inflammation (A and C) and hyperplasia (B and D) scores in the corpus/antrum $(\mathrm{C} / \mathrm{A})$ junction and antrum at one month $(\mathrm{A}$ and $\mathrm{B})$ and three months $(\mathrm{C}$ and $\mathrm{D})$ of infection ( $\mathrm{n}=9-11$ mice per group). Provided are pathological evaluation scores for all gastric tissue sections analyzed and shown in Fig 5. $* P<0.05$, ** $P<0.01$, *** $P<0.001$, Kruskal-Wallis test with Dunn's multiple test correction. 